\title{
The iron isotopic composition of subglacial streams draining the Greenland ice sheet
}

\author{
Stevenson, E.I. ${ }^{* 1,2}$, Fantle, M.S. ${ }^{3}$, Das, S.B. ${ }^{4}$, Williams, H.M. ${ }^{2}$, Aciego, S.M. ${ }^{1}$ \\ ${ }^{1}$ Department of Earth and Environmental Sciences, University of Michigan, 2534 C.C. Little Building, 1100 North \\ University Ave., Ann Arbor, MI 48109-1005, USA \\ ${ }^{2}$ Now at The Department of Earth Sciences, University of Cambridge. Downing Street, Cambridge, CB2 3EQ \\ ${ }^{3}$ Department of Geosciences, The Pennsylvania State University, University Park, PA 16802, USA. \\ ${ }^{4}$ Department of Geology and Geophysics, Woods Hole Oceanographic Institution, Woods Hole, MA 02543, USA. \\ *Corresponding author: eis22@cam.ac.uk
}

Published in Geochemica Cosmochimica Acta 213, p 237-254 
Abstract:

In this study, we present the first measurements of iron ( $\mathrm{Fe})$ stable isotopic composition $\left(\delta^{56} \mathrm{Fe}\right)$ of subglacial streams draining the Greenland Ice Sheet (GIS). We measure the $\delta^{56} \mathrm{Fe}$ values $\left[\left(\delta^{56} \mathrm{Fe}, \%_{0}=\right.\right.$ $\left.\left.\left({ }^{56} \mathrm{Fe} /{ }^{54} \mathrm{Fe}\right)_{\text {sample }} /\left({ }^{56} \mathrm{Fe} /{ }^{54} \mathrm{Fe}\right)_{\text {standard }}-1\right) \times 10^{3}\right]$ of both dissolved and suspended sediment $\mathrm{Fe}$ in subglacial outflows from five distinct land-terminating glaciers. Suspended sediments have $\delta^{56} \mathrm{Fe}$ values that lie within the crustal array $\left(\delta^{56} \mathrm{Fe} \sim 0 \%\right.$ ). In contrast, the $\delta^{56} \mathrm{Fe}$ values of dissolved $\mathrm{Fe}$ in subglacial outflows are consistently less than $0 \%$, reaching a minimum of $-2.1 \%$ in the outflow from the Russell Glacier. The $\delta^{56} \mathrm{Fe}$ values of dissolved Fe vary geographically and on daily time scales. Major element chemistry and mineral saturation state modeling suggest that incongruent silicate weathering and sulphide oxidation are the likely drivers of subglacial stream $\mathrm{Fe}$ chemistry, and that the extent of chemical weathering influences the $\delta^{56} \mathrm{Fe}$ of dissolved $\mathrm{Fe}$. The largest difference in $\delta^{56} \mathrm{Fe}$ between dissolved and suspended load is $-2.1 \%$, and occurs in the subglacial system from the Russell glacier (southwest GIS). Major element chemistry indicates this outflow to be the least chemically weathered, while more mature subglacial systems (i.e., that exhibit greater extents of subglacial weathering) have dissolved loads with $\delta^{56} \mathrm{Fe}$ that are indistinguishable from suspended sediments $\left(\Delta^{56} \mathrm{Fe}_{\text {suspended-dissolved }} \sim 0 \%\right.$ ). Ultimately, the dissolved $\mathrm{Fe}$ generated in some subglacial systems from the GIS is a previously unrecognized source of isotopically light $\mathrm{Fe}$ into the hydrosphere. The data illustrate that the dissolved $\mathrm{Fe}$ supplied by subglacial weathering can have variable $\delta^{56} \mathrm{Fe}$ values depending on the degree of chemical weathering. Thus, Fe isotopes have potential as a proxy for subglacial chemical weathering intensity or mode. Finally, based on our regional $\mathrm{Fe}$ concentration measurements from each

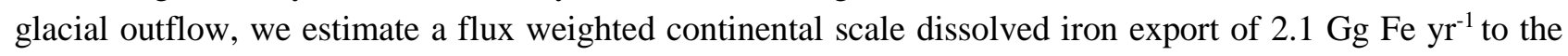
coastal ocean, which is within the range of previous estimates. 
1. Introduction

Constraining iron $(\mathrm{Fe})$ fluxes to the ocean is critical given the role of $\mathrm{Fe}$ as a micronutrient for marine phytoplankton (e.g., Martin et al., 1990; Martin et al., 1994; Martin and Fitzwater, 1988; Martin et al., 1991). The bioavailability of Fe can limit photosynthesis in phytoplankton, which in turn can influence atmospheric $\mathrm{CO}_{2}$ concentrations via the biological pump. Thus, variable mass fluxes of Fe to the ocean, especially in those regions of the ocean that are high in macronutrients but limited with respect to $\mathrm{Fe}$ (so-called high nutrient, low chlorophyll, or HNLC, regions), can influence climate (e.g., Boyd, 2008; Jickells et al., 2005; Mahowald et al., 2005; Mahowald et al., 2006; Raiswell and Canfield, 2012). Such a mechanism has been inferred to operate during the Last Glacial Maximum (LGM), during which time atmospheric dust inputs to the ocean were greater than today, which stimulated enhanced $\mathrm{CO}_{2}$ drawdown through productivity in the ocean (Martin, 1990). On the modern Earth, $\mathrm{Fe}$ is delivered to the global ocean from continents predominantly via rivers and dust (e.g., Boyd and Ellwood, 2010; Crusius et al., 2011; Fantle and DePaolo, 2004; Fung et al., 2000; Jickells and Spokes, 2001; Schroth et al., 2014), though at high latitudes glacially derived Fe may represent a significant flux of Fe to the ocean. Because the major HNLC regions lie at high latitudes (i.e., the subArctic Pacific and the Southern Ocean), glacially derived Fe fluxes to HNLC regions may have a significant impact on primary productivity and associated $\mathrm{CO}_{2}$ drawdown.

Subglacial streams may represent a sizeable Fe flux that is able to influence ocean chemistry over glacial, or even geological, time scales. For instance, recent work on the Greenland Ice Sheet (GIS) suggest subglacial streams are globally significant sources of labile (bioavailable) Fe to the euphotic zone of coastal oceans (e.g., Bhatia et al., 2013a; Hawkings et al., 2014). Subglacial streams do more than mobilize melting ice; they also sample the subglacial weathering system. Subglacial

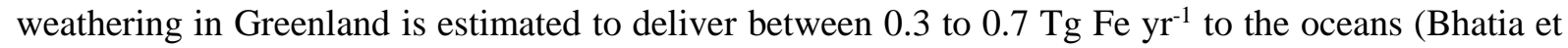
al., 2013a; Hawkings et al., 2014), which is comparable to both the modern soluble dust flux to the oceans (0.07 to $0.7 \mathrm{Tg} \mathrm{Fe} \mathrm{yr}^{-1}$; (Boyd et al., 2010; Fan et al., 2006)) and the modern riverine flux (0.14 $\mathrm{Tg} \mathrm{Fe} \mathrm{yr}^{-1}$; (Raiswell and Canfield, 2012)). If subglacial systems do turn out to be important sources of Fe to the global ocean, then it is important to understand (i) which processes that generate and control these fluxes and thus (ii) how the fluxes may vary geographically and temporally. Over geological time scales, the Greenland Ice Sheet has contracted and expanded in response to dramatic and rapid shifts in climate. If such changes in the ice sheet can be mechanistically tied to the temporal evolution of Fe mass fluxes, then one may be able to estimate the changes expected in Fe mass fluxes over time from subglacial sources.

Iron isotopes might prove useful for constraining Fe fluxes and the process (or processes) by which $\mathrm{Fe}$ is released from, and/or sequestered within, weathering systems at regional or watershed 
spatial scales. As has been demonstrated for other Fe sources to the North Atlantic (Conway and John, 2014; Zhang et al., 2015), constraining the Fe isotopic composition of glacial melt waters (expressed as $\delta^{56} \mathrm{Fe}$ or $\delta^{57} \mathrm{Fe}$ in the literature) may facilitate the tracing of glacial $\mathrm{Fe}$ in proximal oceans. Such constraints are not straightforward to obtain, as there is reason to suspect that the Fe isotopic composition of subglacial streams may vary considerably. Work to date has shown that rivers generally have variable $\delta^{56} \mathrm{Fe}$ values (e.g., Bergquist and Boyle, 2006; Chen et al., 2014; Escoube et al., 2015; Fantle and DePaolo, 2004). In addition, it is expected that the geochemistry of glacial streams is impacted by subglacial weathering processes such as ice-rock grinding, water-rock interaction, and microbial activity that have been documented to fractionate Fe isotopically (e.g., Fantle and DePaolo, 2004; Kiczka et al., 2011; Wiederhold et al., 2007a, b)).

The expectation of considerable variability in $\delta^{56} \mathrm{Fe}$ in the sub-glacial setting derives from the understanding that aqueous $\mathrm{Fe}$ occurs in multiple oxidation states in natural waters and is extensively cycled between these oxidations states in natural systems. Dissolved Fe in glacial melt waters occurs as ferrous Fe(II) derived from weathering of sulphides and silicates and/or as a product of microbial respiration (Wadham et al., 2010a; Wadham et al., 2010b), as well as Fe(III) derived from weathering of silicates and oxides and oxidation of $\mathrm{Fe}$ (II), oxidation state exerts a major control on Fe isotopes, the maximum isotopic fractionation ( $3 \%$ ) occurs between aqueous $\mathrm{Fe}(\mathrm{II})$ and $\mathrm{Fe}$ (III) (Anbar et al., 2005; Johnson et al., 2002) thus it is expected that Fe cycling in redox-active subglacial systems should generate considerable variability in $\delta^{56} \mathrm{Fe}$. For example, ferrous $\mathrm{Fe}$ can be generated, and potentially maintained subglacially, by microbially catalyzed reduction of $\mathrm{Fe}$ oxy-hydroxides in anoxic microcosms or widespread anoxic systems (Bottrell and Tranter, 2002; Hawkings et al., 2014; Tranter et al., 2002), potentially generating significant $\mathrm{Fe}$ isotopic fractionation. Likewise, non-redox chemical reactions involving Fe have also been associated with large isotopic effects (e.g. Anbar et al., 2000; Kiczka et al., 2010; Skulan et al., 2002; Thompson et al., 2007; Welch et al., 2003; Zhang et al., 2015). For example, isotopic effects as large as $4 \%$ have been associated with organic-Fe complexation (e.g. Bullen et al., 2001; Dideriksen et al., 2008; Ilina et al., 2013), abiotic precipitation of Fe(III) (e.g. Balci et al., 2006), and silicate weathering (Kiczka et al., 2011). Because the generation of fresh, finely ground rock flour by ice-rock interactions is significant in subglacial environments, it is expected that $\mathrm{Fe}$ isotopic composition in chemical weathering products should vary considerably in glacial systems.

Given the basic importance of constraining the Fe isotopic composition of what might be a sizeable input to the global ocean, as well as assessing the potential for Fe isotopes to fingerprint the key processes that drive Fe release in subglacial settings, the current study investigates the spatial and temporal (daily) variability in Fe concentrations and Fe isotopic compositions from the Greenland Ice Sheet. The dissolved and suspended loads of glacial outflow are sampled from glaciers that vary in 
bedrock geology, size, and local seasonal climate (Aciego et al., 2015), in order to evaluate the hypothesis that the extent of chemical weathering controls the Fe isotopic composition of dissolved Fe. The data demonstrate that, within a given glacial system, the $\delta^{56} \mathrm{Fe}$ values of dissolved $\mathrm{Fe}$ are substantially lower than the $\delta^{56} \mathrm{Fe}$ of corresponding suspended sediments, and that the $\mathrm{Fe}$ isotopic compositions of both the suspended sediment and dissolved loads are generally consistent for a given glacial outflow over the time frame sampled. Ultimately, the highly fractionated source of $\mathrm{Fe}$ transported in subglacial outflows may play an important role in determining the $\delta^{56} \mathrm{Fe}$ of reservoirs and fluxes within the global Fe cycle.

\section{Sample locations and methods}

\subsection{Location of glacial outlets}

Samples were collected from five land terminating glaciers around the western and southern margin of the Greenland Ice sheet (Aciego et al., 2015), and the Saqqarliup Sermia (GIL) (Fig. 1). Each sample site is located directly at the outflow terminus of a Greenland ice sheet outlet glacier (between 12-40 km in length), and sits atop bedrock of varying ages and lithologies. Each glacial outflow was sampled during peak melt as inferred from local; climatological data (Aciego et al., 2015), in summary:

The Qoorqup Sermia (GNR, 45¹9.765 W, 61 ${ }^{\circ} 12.466 \mathrm{~N}$, Fig. 1b) is located $\sim 8 \mathrm{~km}$ northeast of Narsarsuaq. This land terminating glacier first drains into the glacier valley Blomsterdalen then into the Tunulliarfik fjord (Skovfjorden). The outlet glacier rests on part of the Garder Intrusive Complex but the ice sheet is primarily resting on granite/granodiorite (1.8 Ga) (Henriksen et al., 2009).

The Saqqarliup Sermia (GIL, 50 $16.133 \mathrm{~W}, 68^{\circ} 02.567 \mathrm{~N}$, Fig. 1c) is our northern-most study site, and is a largely marine terminating outlet glacier that drains into the Sarqardleq-Tasiussaq fjord system which is connected to Jakobshavn Isfjord $\sim 30 \mathrm{~km}$ to the north, and ultimately Disko Bay. This glacier is $6 \mathrm{~km}$ across at the terminus and has an overall catchment of roughly $400 \pm 50 \mathrm{~km}^{2}$, its subglacial meltwater discharge is sourced from multiple distinct subglacial catchments (Stevens et al., 2016). In this study we sampled from a small sub-catchment that has a sub-aerial outlet near sea level at the far western margin of GIL. The bedrock geology is inferred to consist primarily of quartz diorite rocks of the Nagssugtqidian Orogenic Complex (K/Ar age 1790-1650 Ma), most likely from an intrusive sheet metamorphosed in its outer parts (Escher, 1971). 

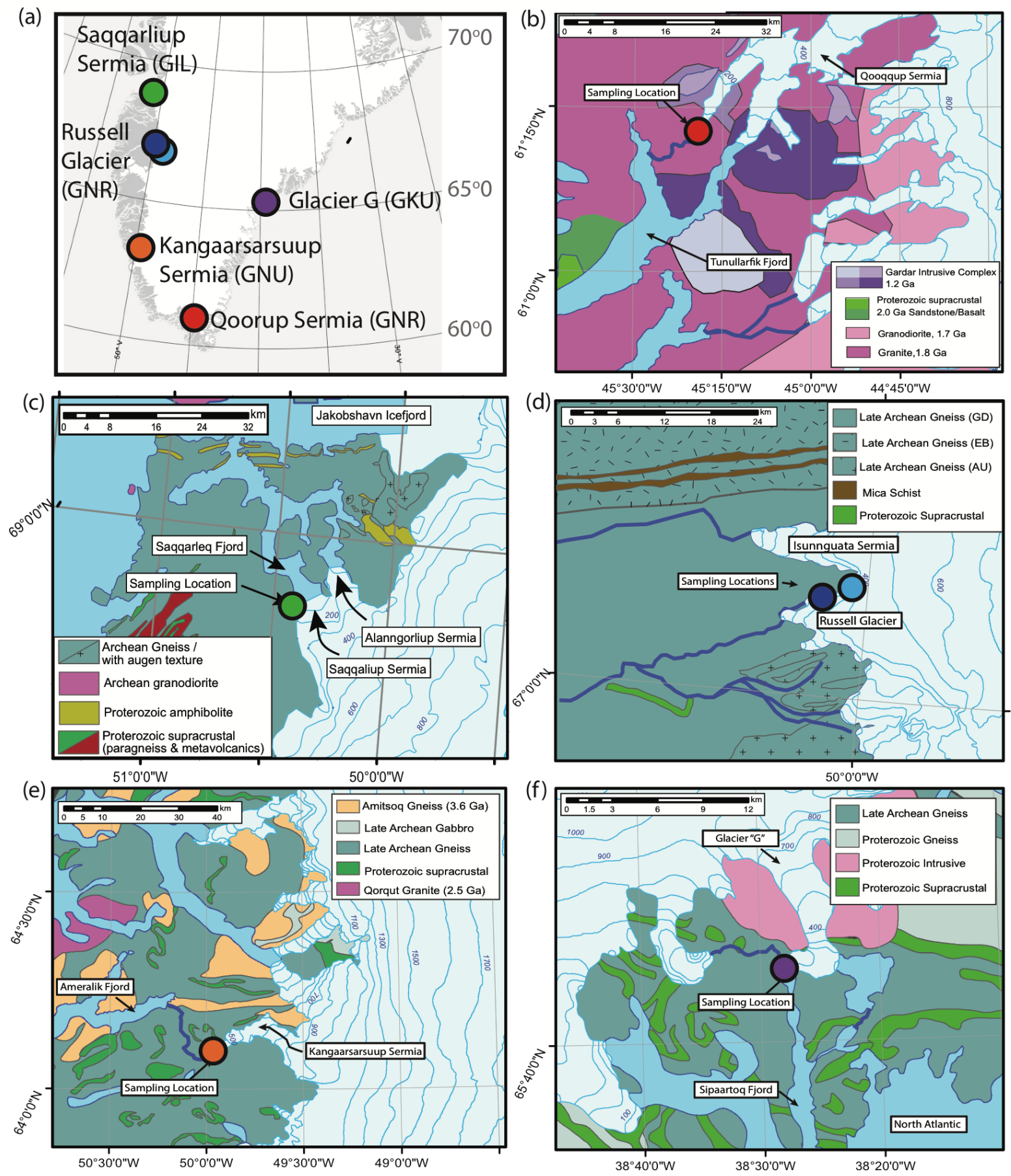

Figure 1: (a) Geographical location of sample sites in southern Greenland. (b)-(f), Pale blue lines are $100 \mathrm{~m}$ contour lines of the glaciers and dark blue lines represent the seawater-land boundary. Rivers are also in dark blue. Bedrock lithology surrounding each glacial region sampled is modified from Aciego et al. (2015), see text for further lithological details. (b) The Qoorqup Sermia (GNR) rests on part of the Garder Intrusive Complex but the ice sheet is primarily resting on granite/granodiorite $(1.8 \mathrm{Ga})$. (c) The GIL sits atop mainly Archean Gneiss with augen texture. (d) Russell Glacier (GKL), northeast of Kangerlussuaq rests on the suture zone between several orthogneiss units (large scale faults run E-W), GD refers to granite/granodiorite, EB refers to enderbetic and AU refers to augen texture. Two marginal outlet of the Russell were sampled, GKLa and GKLb. (e) The Kangaarsarsuup Sermia (GNU) sits atop mixed Late Archean gneiss and Proterozoic supracrustal bedrock (Manning et al., 2006), and is in close proximity to Amitsoq Gneiss (3.8 Ga). (f) Glacier 'G', (GKU) rests on mixed Late Archean gneiss and Proterozoic supracrustal bedrock the units directly underlying Glacier ' $G$ ' are intrusive granodiorite (Henriksen et al., 2009). 
We sampled directly from the glacial outflows of two distinct outlets from the Russell Glacier region (GKL, Fig. 1d), designated Russell Glacier east (GKLa, 5003.549 W, 6708.114 N) and Russell Glacier west (GLKb, 50 $03.997 \mathrm{~W}, 67^{\circ} 09.662 \mathrm{~N}$ ). The Russell glacier lies approximately 24 $\mathrm{km}$ northeast of Kangerlussuaq and rests on the suture zone between several orthogneiss units (largescale faults run E-W, see Fig. 1d), with granite/granodiorite, enderbetic and augen textures (Henriksen et al., 2009).

The Kangaarsarsuup Sermia (GNU, 49 57.123 W, $64^{\circ} 06.167$ N, Fig. 1e) lies further south, approximately $45 \mathrm{~km}$ southeast from the capital city Nuuk. Regions surrounding Kangerlussuaq and Nuuk are dominated regionally by granodiorite gneiss with local mica-rich schists and metasediments. The KS sits atop mixed Late Archean gneiss and Proterozoic supracrustal bedrock, and is in close proximity to Amitsoq Gneiss (3.8 Ga). Early Archean gneisses, including the Isua supergroup, are also exposed in a small wedge in the Nuuk vicinity (Henriksen et al., 2009).

Glacier ' $G$ ' (GKU, $38^{\circ} 27.524 \mathrm{~W}, 65^{\circ} 42.597 \mathrm{~N}$, Fig. 1f) is approximately $60 \mathrm{~km}$ southwest of Kulusuk and rests on mixed Late Archean gneiss and Proterozoic supracrustal bedrock, however the ice sheet margin in the region has bedrock composed of Proterozoic intrusives (primarily granite). Kulusuk is regionally dominated by granodiorite gneiss (similar to Kangerlussuaq); the units directly underlying Glacier ' $G$ ' are intrusive granodiorite (Henriksen et al., 2009).

\subsection{Sampling methods and analysis}

\subsubsection{Pre-cleaning}

All materials used for field collection, decontamination and processing were pre-cleaned using double-distilled acids (Fisher Optima or Seastar) and ultra high purity deionized water (SQDI; >18.2 $\mathrm{M} \Omega \cdot \mathrm{cm}$ DI water) in a metal-free class 10,000 (ISO 7) clean laboratory under class 100 (ISO 5) laminar flow hoods in the Glaciochemistry and Isotope Geochemistry Laboratory at the University of Michigan, then sealed in sterile bags and shipped to the field sites. Low density polyethylene (LDPE) Nalgene bottles, and polypropylene centrifuge tubes, and tubes were rinsed with SQDI water, leached for 48 hours in $1 \mathrm{M}$ reagent grade nitric acid, rinsed three times with SQDI water, leached for 48 hours in $1 \mathrm{M}$ double-distilled hydrochloric acid, and rinsed three times with SQDI water. Tygon 2001 pump tubing (chemically resistant) was rinsed with SQDI water, leached for 72 hours in $1 \mathrm{M}$ double-distilled hydrochloric acid, and rinsed three times with SQDI. Teflon (FEP and PTFE) materials, Savillex® filtration units and connectors, were cleaned by submersion sequentially in $14 \mathrm{M}$ nitric acid, $12 \mathrm{M}$ hydrochloric acid, $14 \mathrm{M}$ nitric with trace $27 \mathrm{M}$ hydrofluoric acid at $100^{\circ} \mathrm{C}$ for at least 24 hours each then triple rinsed in SQDI water. 


\subsubsection{Collection of subglacial water and suspended sediment}

The solute load of bulk glacier outflows can increase significantly with distance across glacier forelands (Anderson, 2007), which has important implications for the locations of sampling sites. Unless water is sampled close to the glacier terminus, its hydrochemistry will have a proglacial signature superimposed on its glacial signal. Therefore, all glacial outflows were sampled directly from the glacial terminus with the exception of the GNR, which was sampled $\sim 50$ m downstream due to logistical difficulties approaching the glacial termini (i.e. topography). For all sites sampling locations were chosen to avoid any other hydrological inputs into the bulk subglacial outflow, and samples were taken mid stream (where logistically possible), at a depth of $\sim 30 \mathrm{~cm}$. Each data point represents a single sample taken on an individual day and was taken between 9 am and 10 am local time. The exception was for GKU (south GIS) where on the final day of sampling samples were taken at both 9.30 am (GKU-140813a) and 16.20 pm (GKU-140813b) to test if bulk glacial outflows can exhibit diurnal variation in $\delta^{56} \mathrm{Fe}$ compositions.

Samples were typically filtered within one hour of sampling and never more than two hours after sampling. Subglacial water was filtered using a Masterflex modular peristaltic pump and a Perfluoroether (PFA) $47 \mathrm{~mm}$ filtration unit (Savillex). Hydrophobic Polyvinylidene fluoride (PVDF) filter membranes $(0.2 \mu \mathrm{m})$ were used to separate the suspended sediment. One liter of ultra-pure SQDI water was filtered through the system prior to filtration of samples. Subglacial water was filtered and collected directly from the main melt channel at the toe of the each glacier into the precleaned $1 \mathrm{~L}$ Nalgene bottles and acidified to $\mathrm{pH}<2$ on the day of collection (after alkalinity measurements, see Section 2.2.3) with double-distilled $10 \mathrm{M}$ hydrochloric acid, $1 \mathrm{~mL}$. An additional sample of filtered water $(\sim 100 \mathrm{~mL})$ was left unacidified and kept for anion analysis. The $0.22 \mu \mathrm{m}$ Millipore filter containing the suspended sediment was carefully removed using gloved hands and archived in a pre cleaned centrifuge tube. We define our dissolved load (DL) to be $<0.22 \mu \mathrm{m}$, though the functional pore size may be lowered as material accumulates on the filter as filtration progresses (Howard, 2010; Raiswell and Canfield, 2012), it is also likely that our dissolved load additionally includes colloidal and nanoparticulate $\mathrm{Fe}$ which can be smaller than $0.22 \mu \mathrm{m}$. Therefore suspended sediment (SS) is defined as $>0.22 \mu \mathrm{m}$.

\subsubsection{In-field water quality measurements}

Daily electrical conductivity, temperature, $\mathrm{pH}$, and alkalinity measurements were taken using a YSI multiparameter meter as previously reported in Aciego et al. (2015). The calibration of the $\mathrm{pH}$ probe on the YSI multiparameter meter was checked daily prior to alkalinity measurements, and re- 
calibrated when necessary with $\mathrm{pH} \mathrm{4,7}$ and 10 solutions. Each measurement was conducted on-site in the subglacial outlet channels by submerging the probe into the moving water and waiting for the meter to equilibrate immediately prior to sample collection. Approximately $100 \mathrm{~mL}$ of filtered subglacial water was used for alkalinity measurements. For anticipated low alkalinities, the $100 \mathrm{~mL}$ sample was mixed with $1 \mathrm{~mL}$ of Total Alkalinity Reagent solution (and for high alkalinities, $10 \mathrm{~mL}$ Total Alkalinity Reagent solution), shaken, then the $\mathrm{pH}$ measured and converted to total alkalinity (ppm $\mathrm{CaCO}_{3}$ ) using a pH-total alkalinity conversion (Fujita et al., 2008; Hedin et al., 1994).

\subsubsection{Sample preparation}

Archived water samples, $1 \mathrm{~L}$, were evaporated to dryness on a hotplate. Suspended sediment was carefully removed from the filter with SQDI water then dried. Ten milligrams of sediment was weighed and digested for seven days in $2 \mathrm{~mL} 14 \mathrm{M}$ nitric acid with $0.5 \mathrm{~mL} 27 \mathrm{M}$ hydrofluoric acid on a hot plate. Sediment samples were dried down and further digested in aqua regia (a mixture of double-distilled $14 \mathrm{M}$ nitric acid and $12 \mathrm{M}$ hydrochloric acid) for 24 hours to oxidize any residual organic material before drying and dissolving in $9 \mathrm{M}$ double-distilled hydrochloric acid.

\subsubsection{Elemental analysis}

Elemental analysis is described in Aciego et al. (2015); trace and minor element concentrations ( $\mathrm{Fe}, \mathrm{Si}, \mathrm{Al}, \mathrm{Mg}, \mathrm{K}, \mathrm{Na}$ and $\mathrm{Ca}$ ) were determined by analyzing $3 \mathrm{~mL}$ aliquots of each water sample on the Thermo Scientific ELEMENT2 ICP-MS at the University of Michigan Keck Laboratory operating in pulse counting mode. An acid blank and multi-elemental standards (SigmaAldrich ${ }^{\circledR}$ ) were run every five samples to assess within-run reproducibility and accuracy; long term reproducibility and accuracy was assessed by measurement of river standard NIST 1640a and USGS rock standards BCR-2 and AGV-2. Measurements of international standard NIST1640a, USGS standards BCR-2 and AGV-2, and a procedural blank are provided in the Supplementary Information. Baseline detection measurements from the total procedural blank indicate that analytical error was never greater than $10 \%$, the concentration even for the smallest concentrations (Aciego et al., 2015). Anion concentrations $\left(\mathrm{SO}_{4}{ }^{2}\right.$ and $\mathrm{Cl}$ ) were determined on a Dionex 3000 IC system at Byrd Polar Research Center, Ohio State University (data presented in Supplemental Table 1).

\subsubsection{Iron isotopic analysis}

Dissolved load waters and suspended sediments were prepared to provide between 1 to $300 \mu \mathrm{g}$ Fe (Section 2.2.4). All hydrochloric acid used during elemental separation was high-purity grade (e.g., Fisher Optima ${ }^{\circledR}$ or Seastar $\left.{ }^{\circledR}\right)$. Samples were chromatographically purified at The University of 
Michigan using $0.6 \mathrm{~mL}$ Bio-Rad $\mathrm{AG}{ }^{\circledR} 1-\mathrm{X} 4$ resin beds, which were preconditioned in $6.0 \mathrm{~N}$ hydrochloric acid. Samples were dissolved in $0.5 \mathrm{~mL} 6.0 \mathrm{~N}$ hydrochloric acid and loaded onto preconditioned columns in $0.5 \mathrm{~mL}$ aliquots. The loaded sample was rinsed with $4 \mathrm{~mL}$ of $6.0 \mathrm{~N}$ hydrochloric acid in $0.5 \mathrm{~mL}$ aliquots, and $\mathrm{Fe}$ was eluted using $8 \mathrm{~mL}$ of $2.0 \mathrm{~N}$ hydrochloric acid (Williams et al., 2004). Suspended sediment samples were passed through column chemistry twice to minimise any isobaric interference from $\mathrm{Cr}$. After column purification, dried samples were treated with $1 \mathrm{~mL}$ of concentrated double-distilled nitric acid (approximately $14 \mathrm{~N}$ ) and $1 \mathrm{~mL}$ of hydrogen peroxide (30\% w/w, Fisher Optima ${ }^{\circledR}$ ) and dried. Column yields were $\geq 95 \%$. Single-element, highpurity Fe ICP-MS standards were analyzed before and after ion exchange purification of Fe to verify that column chemistry does not alter the isotopic composition of the samples. Analysis of an $\mathrm{Fe}$ standard run before and after column chemistry yielded $\delta^{56} \mathrm{Fe}$ values within $0.05 \%$ of the true value, thus demonstrating no measureable fractionation due to column chemistry when yields are $>95 \%$.

Iron isotopic analyses were conducted by multiple collector inductively coupled plasma mass spectrometry (MC-ICP-MS) using a Thermo Scientific Neptune Plus at Pennsylvania State University’s Metal Isotope Laboratory (MIL). Samples were introduced using an ESI ${ }^{\circledR}$ SSI quartz dual cyclonic spray chamber (i.e., under wet plasma conditions), a $100 \mu 1 /$ min nebulizer flow rate (ESI PFA-100 microflow nebulizer), $1200 \mathrm{~W}$ power, standard $\mathrm{Cu}$-cored $\mathrm{Ni}$ cones, and a high mass resolution slit; during all analytical sessions, room temperatures typically varied by less than $0.1^{\circ} \mathrm{C} / \mathrm{hr}$. All analyte solutions were matrix matched to the IRMM-014 bracketing standard (Fe concentrations $=$ $3 \mathrm{ppm}$ in $0.5 \mathrm{~N}$ nitric acid; ${ }^{56} \mathrm{Fe}$ beam intensities were between 8 and $15 \mathrm{~V}$, depending on the analytical session and nebulizer used). Delta values were determined by standard-sample-standard bracketing. All ion beams were collected in a single, static scan (integration time=8 sec, 35 cycles/analysis). Plateau tests conducted during methodological development determined the mass range over which the plateau was effectively flat, and all subsequent analyses were confined to this part of the plateau. Chromium was monitored at masses 52 and 53, and offline interference corrections applied for data quality purposes only; no $\mathrm{Cr}$-corrected data are reported in this study, nor were any $\mathrm{Cr}$ corrections required. All ${ }^{52} \mathrm{Cr} /{ }^{56} \mathrm{Fe}$ ratios were below 0.00010 , with the average value for all analyses $0.000023 \pm$ 0.000023 (1SD). All analyses fall on the mass dependent fractionation line on an isotope-isotope plot (Supplementary Figure 1). Two inter-laboratory standards were run in each analytical session between 12/18/2012 and 10/27/2014: over this period, the average $\delta^{56} \mathrm{Fe}_{\mathrm{IRMM} 014}$ value for NIST SRM 3126a is $0.35 \pm 0.062 \mathrm{SD} \%$ ( $n=32$; accepted value: $0.35 \%$; e.g. Rouxell and Auro 2010) while that of HPSUW is $0.57 \pm 0.062 \mathrm{SD} \%$ ( $n=30$; accepted value: $0.58 \%$; e.g. Beard et al., 2003a; Beard et al., 2003b). In addition, process replicate analyses of BCR-1 have an average $\delta^{56} \mathrm{Fe}_{\mathrm{IRMM} 014}$ of $0.12 \pm$ 0.09\% ( $\mathrm{n}=3$; 2SD; previously measured values: 0.08 to 0.12\%; (Dauphas and Rouxel, 2006; 
Zambardi et al., 2014); similar $\delta^{56} \mathrm{Fe}$ values are reported for BCR-2: $0.09 \pm 0.04 \%$ (2SD); (Craddock and Dauphas, 2010).

\section{Results}

Greenland ice sheet glacier outflow waters displayed variable water geochemistry $(\mathrm{pH}$, alkalinity and conductivity) and total iron concentration between glaciers (see Aciego et al. (2015)) and Supplementary Information). However, at individual outlets, their geochemistry was relatively stable over the course of several days of sampling, suggesting that similar hydrochemical processes were maintained over the course of sampling, the greatest amount of geochemical variability was observed at the GNR outflow. Conductivity was uniformly low, $<15 \mu \mathrm{S}$, in all catchments, as is typical for western Greenland (Bhatia et al., 2013a; Ryu et al., 2011; Statham et al., 2008). The highest conductivity and $\mathrm{pH}$ were found in the GNR outflow, averaging $12.1 \mu \mathrm{S}$ and 9.2 respectively. Covariations in water $\mathrm{pH}$ and conductivity were observed across the glaciers with a positive correlation $\left(\mathrm{r}_{\mathrm{s}}=0.79, \mathrm{R}^{2}=0.74\right)$, such that when $\mathrm{pH}$ was low so was conductivity (see Table 1 in Aciego et al. (2015) and Supplemetary Table 1). The ionic strength, a measure of respective charges relative to concentration was an order of magnitude weaker in the two GKL outflows relative to all other sample sites $\left(<0.08 \cdot 10^{3} \mathrm{M}\right.$, Table 1$)$, while the GIL recorded the highest ionic strength $\left(1.34 \cdot 10^{3} \mathrm{M}\right.$, Table 1$)$. The predominant anions in the outflow are $\mathrm{HCO}_{3}{ }^{-}$and $\mathrm{SO}_{4}{ }^{2-}$, most likely derived from the dissolution of carbonate minerals and oxidation of sulfides. Elevated anion, $\mathrm{Na}$ and $\mathrm{Cl}$ concentrations (GIL and GKU), may primarily reflect the proximity of these individual sites to the coast and the strength of the prevailing wind directions. Iron concentrations span a range of magnitudes from $\sim 0.1 \mu \mathrm{M} \mathrm{L}^{-1}$ (GNU) to $\sim 7 \mu \mathrm{M} \mathrm{L}^{-1},(\mathrm{GNR})$, with the most variation within a given outflow from GNR ranging from 0.98 to $6.97 \mu \mathrm{M} \mathrm{L}^{-1}$, (see Table 1 and Aciego et al., 2015). This large range in variability suggests different regions of the GIS may be delivering proportionately different quantities of $\mathrm{Fe}$ to the coastal ocean.

Iron isotopic compositions are presented in Table 1 and Fig. 2; all data include replicate analyses and external reproducibility's reported as two times the standard deviation. The $\delta^{56} \mathrm{Fe}$ values of suspended sediments range from $-0.3 \%$ to $0.19 \%$ and average $\sim 0 \%$, similar to the composition of the continental crust, $\delta^{56} \mathrm{Fe} \sim 0.06 \pm 0.03 \%$, (Beard and Johnson, 2004; Poitrasson, 2006). The $\delta^{56} \mathrm{Fe}$ values of dissolved Fe varied between sites, as well as temporally, and in several glacial outflows were considerably lower than suspended sediments (Fig. 2). For the GNR, GNU and GIL, the dissolved load (DL) $\delta^{56} \mathrm{Fe}$ were within error of the suspended sediment (SS). However, for the GKL (a and b outflows) and the GKU, the dissolved load was isotopically lighter than suspended sediment by $0.7 \%$ to $\sim 2.1 \%$ respectively (Table 1 ). 


\begin{tabular}{|c|c|c|c|c|c|c|c|c|}
\hline Sample & $\mathrm{pH}^{*}$ & $\begin{array}{c}\text { Ionic } \\
\text { Strength } \\
\mathrm{mmol} / \mathrm{L}\end{array}$ & $\mathrm{Fe} \mu \mathrm{mol} / \mathrm{L}^{*}$ & $\begin{array}{c}\delta^{56} \mathrm{Fe} \mathrm{DL} \\
(\% \mathrm{o})\end{array}$ & $\begin{array}{l}2 \text { s.e. } \\
\text { (abs) }\end{array}$ & $\begin{array}{c}\mathrm{wt} \% \\
\mathrm{Fe}\end{array}$ & $\begin{array}{c}\delta^{56} \mathrm{Fe} \\
\mathrm{SS} \\
(\%)\end{array}$ & $\begin{array}{l}2 \text { s.e. } \\
\text { (abs) }\end{array}$ \\
\hline \multirow[t]{2}{*}{ GNR-200713 } & 9.14 & 0.36 & 6.97 & -0.07 & 0.01 & 0.10 & -0.30 & 0.01 \\
\hline & & & & -0.06 & 0.01 & & & \\
\hline \multirow[t]{3}{*}{ GNR-210713 } & 9.10 & 0.35 & 0.98 & -0.13 & 0.01 & 0.09 & -0.04 & 0.01 \\
\hline & & & & -0.11 & 0.01 & & -0.11 & 0.01 \\
\hline & & & & & & & -0.06 & 0.01 \\
\hline \multirow[t]{2}{*}{ GNR-220713 } & 9.13 & 0.36 & 4.17 & -0.14 & 0.01 & 0.10 & -0.09 & 0.01 \\
\hline & & & & -0.10 & 0.01 & & & \\
\hline \multirow[t]{2}{*}{ GNR-240713 } & 9.60 & 0.37 & 4.12 & -0.14 & 0.01 & 0.10 & -0.14 & 0.01 \\
\hline & & & & -0.13 & 0.01 & & -0.16 & 0.01 \\
\hline \multirow[t]{2}{*}{ GIL-290713 } & 7.81 & 1.34 & 7.22 & -0.06 & 0.02 & 0.10 & 0.04 & 0.01 \\
\hline & & & & 0.02 & 0.01 & 0.10 & 0.01 & 0.02 \\
\hline \multirow[t]{2}{*}{ GKL-0308313a } & 6.50 & 0.07 & 0.71 & -0.68 & 0.01 & 0.24 & 0.00 & 0.01 \\
\hline & & & & -0.64 & 0.01 & & 0.04 & 0.01 \\
\hline \multirow[t]{3}{*}{ GKL-030813b } & 6.26 & 0.06 & 0.42 & -1.79 & 0.01 & 0.07 & 0.05 & 0.01 \\
\hline & & & & -1.58 & 0.01 & & 0.03 & 0.01 \\
\hline & & & & -1.50 & 0.01 & & & \\
\hline \multirow[t]{3}{*}{ GKL-040813a } & 6.35 & 0.05 & 0.44 & -1.81 & 0.01 & 0.16 & -0.01 & 0.01 \\
\hline & & & & -1.79 & 0.01 & & -0.05 & 0.01 \\
\hline & & & & -1.76 & 0.01 & & & \\
\hline \multirow[t]{3}{*}{ GKL-040813b } & 6.42 & 0.08 & 0.45 & -1.98 & 0.01 & 0.12 & -0.08 & 0.01 \\
\hline & & & & -2.12 & 0.01 & & -0.01 & 0.01 \\
\hline & & & & -2.06 & 0.01 & & & \\
\hline \multirow[t]{3}{*}{ GNU-060813 } & 8.27 & 0.33 & 0.13 & 0.02 & 0.01 & 0.18 & 0.03 & 0.01 \\
\hline & & & & -0.02 & 0.01 & & 0.19 & 0.01 \\
\hline & & & & 0.03 & 0.01 & & 0.00 & 0.01 \\
\hline \multirow[t]{2}{*}{ GNU-070813 } & 8.11 & 0.25 & 0.25 & -0.31 & 0.01 & 0.07 & 0.04 & 0.01 \\
\hline & & & & & & & -0.01 & 0.01 \\
\hline \multirow[t]{2}{*}{ GNU-080813 } & 8.38 & 0.22 & 0.31 & -0.01 & 0.01 & 0.18 & -0.10 & 0.01 \\
\hline & & & & -0.06 & 0.01 & & -0.02 & 0.01 \\
\hline \multirow[t]{2}{*}{ GKU-110813 } & 8.51 & 0.27 & 0.26 & -0.19 & 0.01 & 0.30 & -0.06 & 0.01 \\
\hline & & & & -0.27 & 0.01 & & -0.05 & 0.01 \\
\hline \multirow[t]{2}{*}{ GKU-120813 } & 7.82 & 0.21 & 0.28 & -0.82 & 0.02 & 0.36 & -0.05 & 0.01 \\
\hline & & & & -0.89 & 0.01 & & -0.09 & 0.01 \\
\hline \multirow[t]{3}{*}{ GKU-130813 } & 8.50 & 0.16 & 0.30 & -0.65 & 0.02 & 0.30 & 0.03 & 0.01 \\
\hline & & & & -0.76 & 0.03 & & -0.02 & 0.01 \\
\hline & & & & -0.66 & 0.02 & & 0.00 & 0.01 \\
\hline \multirow[t]{3}{*}{ GKU-140813a } & 7.66 & 0.21 & 0.28 & -0.88 & 0.01 & 0.11 & -0.01 & 0.01 \\
\hline & & & & -0.92 & 0.01 & & -0.05 & 0.01 \\
\hline & & & & -0.92 & 0.01 & & & \\
\hline \multirow[t]{2}{*}{ GKU-140813b } & 6.88 & 0.13 & 0.31 & -0.72 & 0.01 & 0.07 & -0.01 & 0.01 \\
\hline & & & & -0.73 & 0.01 & & -0.01 & 0.01 \\
\hline
\end{tabular}

* data from Aciego et al. (2015) with the exception of the SQS outflow.

Table 1: Stable Fe isotopic compositions and in-stream measurement data from each glacial outflow. Analytical repeats of iron isotopes are shown for each individual sample. Iron concentration data is from Aciego et al., 2015 with the exception of the samples from GIL. Ionic strength calculated from major element and anion concentrations using PHREEQC. Errors are reported as two standard errors on individual measurements. 


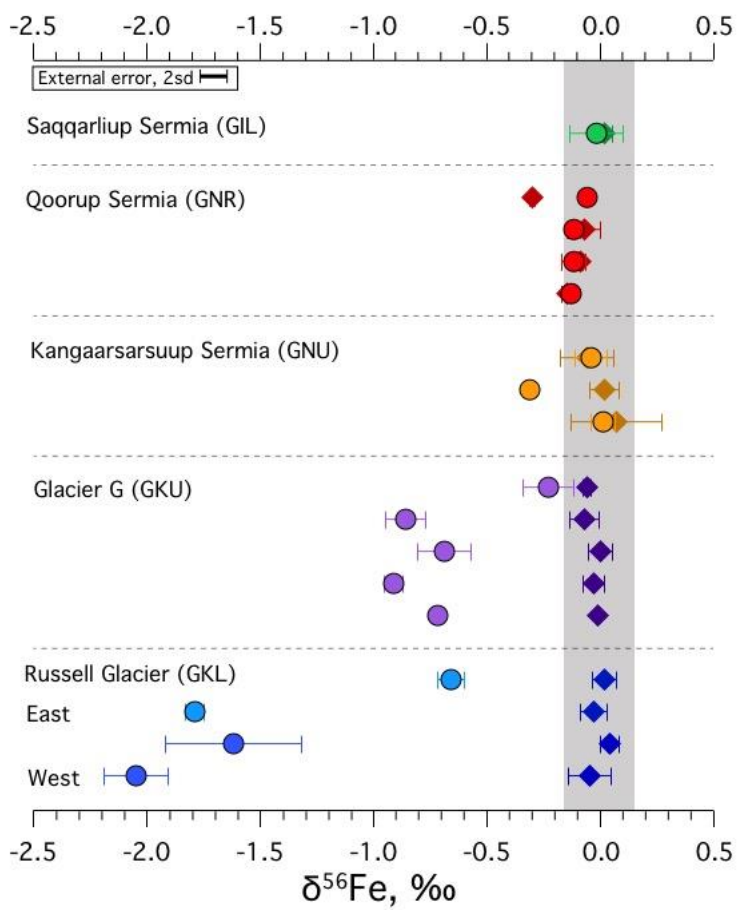

Figure 2: Total range of $\delta^{56} \mathrm{Fe}(\%)$; symbols are coloured according to the sample location, suspended sediments in diamonds and dissolved loads in circles. Each symbol represents the average of repeat measurements with two standard deviations (see Table 1). Symbols on individual lines represent samples taken on different days (see Table 1). External error (as two standard deviations) is shown with the bar in the top left corner.

\section{Discussion}

\subsection{Subglacial streams as indicators of chemical and physical weathering processes}

Chemical weathering processes in subglacial settings differ from those in temperate environments in significant ways: (i) temperatures are lower, which decrease the rates at which chemical reactions occur, (ii) overlying ice restricts the flux of atmospheric gases into the subglacial environment, which impacts the chemistry in such settings, and (iii) ice limits the flux of light, which is required for microbial photosynthesis, into subglacial systems. Soils, if present, are thin and vegetation is either absent or limited in mass/extent (French, 2007; Tranter and Wadham, 2014). However, because physical weathering at the ice-rock interface generates substantial quantities of fine-grained, high surface area to volume material, the subglacial environment is primed for silicate and aluminosilicate weathering. Therefore, despite potential limitations of weathering due to low temperatures and ice cover, glaciers may effectively promote the dissolution and solubilization of minerals within the bedrock, including silicates as well as trace components such as carbonates, sulfides, and fluid inclusions (Tranter and Wadham, 2014). Glacial outflows may therefore provide a means of investigating $\mathrm{Fe}$ isotopic fractionation associated with silicate weathering without large overprinting effects from biological processes such as plant growth. 
The chemical reactions occurring in the subglacial environment can be inferred from the geochemistry of the outflow hydrochemistry from each glacier, which have relatively high $\mathrm{K}^{+}$and $\mathrm{Ca}^{2+}$ concentrations and are dominated by $\mathrm{HCO}_{3}{ }^{-}$. These data, in addition to the clear trend in $\mathrm{Mg} / \mathrm{Na}-$ $\mathrm{Ca} / \mathrm{Na}$ space (Fig. 3a), suggest that silicate weathering mainly influences subglacial water chemistry, though carbonate weathering also clearly occurs (i.e., at GNR and GKL). The presence of significant silicate weathering is supported by molar $\mathrm{K} / \mathrm{Si}$ ratios in outflows, which are generally greater than 0.5 at all sites (Fig. 3b). The majority of GIS outflows have relatively high K/Si ratios (0.44 to 1.67 mol:mol), compared to ostensible parent rock (K/Si < 0.1 for mafic and felsic lithologies). The GKL and GNR outflows have K/Si of $\sim 0.45$, which is higher than that expected for both muscovite and Kfeldspar $(\mathrm{K} / \mathrm{Si} \sim 0.3)$. This is clear evidence of incongruent weathering, during which silica is retained relative to $\mathrm{K}^{+}$in the subglacial weathering system (Anderson, 2005).

Major element chemistry also supports the hypothesis that oxidative pyrite dissolution occurs in these subglacial systems. Sulfate concentrations in subglacial outflow average $17 \mu \mathrm{M}$, excluding the very high sulphate concentration at the GIL outflow (see Supplementary Table 1). The exceptionally high sulphate (and $\mathrm{Cl}$ ) concentration at GIL is most likely sourced from marine origin given the proximity of the glacial outflow to the coast and its discharge into a highly saline fjord $(>24,000 \mu \mathrm{S}$ $\mathrm{cm}^{3}$ ). Sulphide oxidation has been suggested to be a significant geochemical process in subglacial settings, in terms of producing protons and enhancing carbonate and silicate weathering processes (Tranter and Wadham, 2014). In southern Greenland terrains, intrusive and metamorphic pyrite is an accessory mineral (Henriksen et al., 2009) that will continually be exposed to subglacial melt water by the production of fresh surfaces through glacial erosion. Under oxic conditions, sulphides are oxidized by molecular oxygen (Eqns 1a and b), subsequently producing Fe (oxy)hydroxides and protons, which promote $\mathrm{CaCO}_{3}$ and/or silicate dissolution (e.g., Eqns. 1a and 1b). As conditions change from oxic to suboxic and all the way to anoxic, iron is reverted to Fe(III) (Wadham et al., 2010) (e.g. Eqn. 3). Under such conditions, anaerobic organisms can use use sulfate or iron as the final electron acceptor in lieu of oxygen, reducing (III) to Fe(II) (e.g. Eqn 2)

$$
\begin{aligned}
& \mathrm{FeS}_{2(\mathrm{~s})}+3.75 \mathrm{O}_{2(\mathrm{aq})}+3.5 \mathrm{H}_{2} \mathrm{O}_{(\mathrm{l})} \longrightarrow 2 \mathrm{SO}_{4}{ }^{2-}{ }_{(\mathrm{aq})}+\mathrm{Fe}(\mathrm{OH})_{3(\mathrm{~s})}+4 \mathrm{H}^{+} \\
& \mathrm{FeS}_{2(\mathrm{~s})}+3.75 \mathrm{O}_{2(\mathrm{aq})}+0.5 \mathrm{H}_{2} \mathrm{O}_{(\mathrm{l})} \longleftrightarrow 2 \mathrm{SO}_{4}{ }^{2-}{ }_{(\mathrm{aq})}+\mathrm{Fe}^{3+}{ }_{(\mathrm{aq})}+\mathrm{H}^{+} \\
& \mathrm{FeS}_{2(\mathrm{~s})}+14 \mathrm{Fe}^{3+}{ }_{(\mathrm{aq})}+8 \mathrm{H}_{2} \mathrm{O}_{(\mathrm{l})} \longleftrightarrow 15 \mathrm{Fe}^{2+}{ }_{(\mathrm{aq})}+2 \mathrm{SO}_{4}{ }^{2-}{ }_{(\mathrm{aq})}+16 \mathrm{H}^{+}{ }_{(\mathrm{aq})}
\end{aligned}
$$

The analysis above provides important context for understanding the sources of $\mathrm{Fe}$ (as well as its speciation and isotopic composition) to subglacial streams. There are most likely sources of dissolved Fe to subglacial outflow other than sulphide oxidation, which is supported by $\mathrm{Fe}$ and sulfate concentrations that do not generally occur in stoichiometric ratios (i.e., $\mathrm{Fe} / \mathrm{S}=0.5$; Eqn. $2 \mathrm{~b}$; outflows 
generally are $<0.1)$. The exception to this is the GNR outflow, which has a molar Fe/S ratio of $\sim 0.5$

(a)
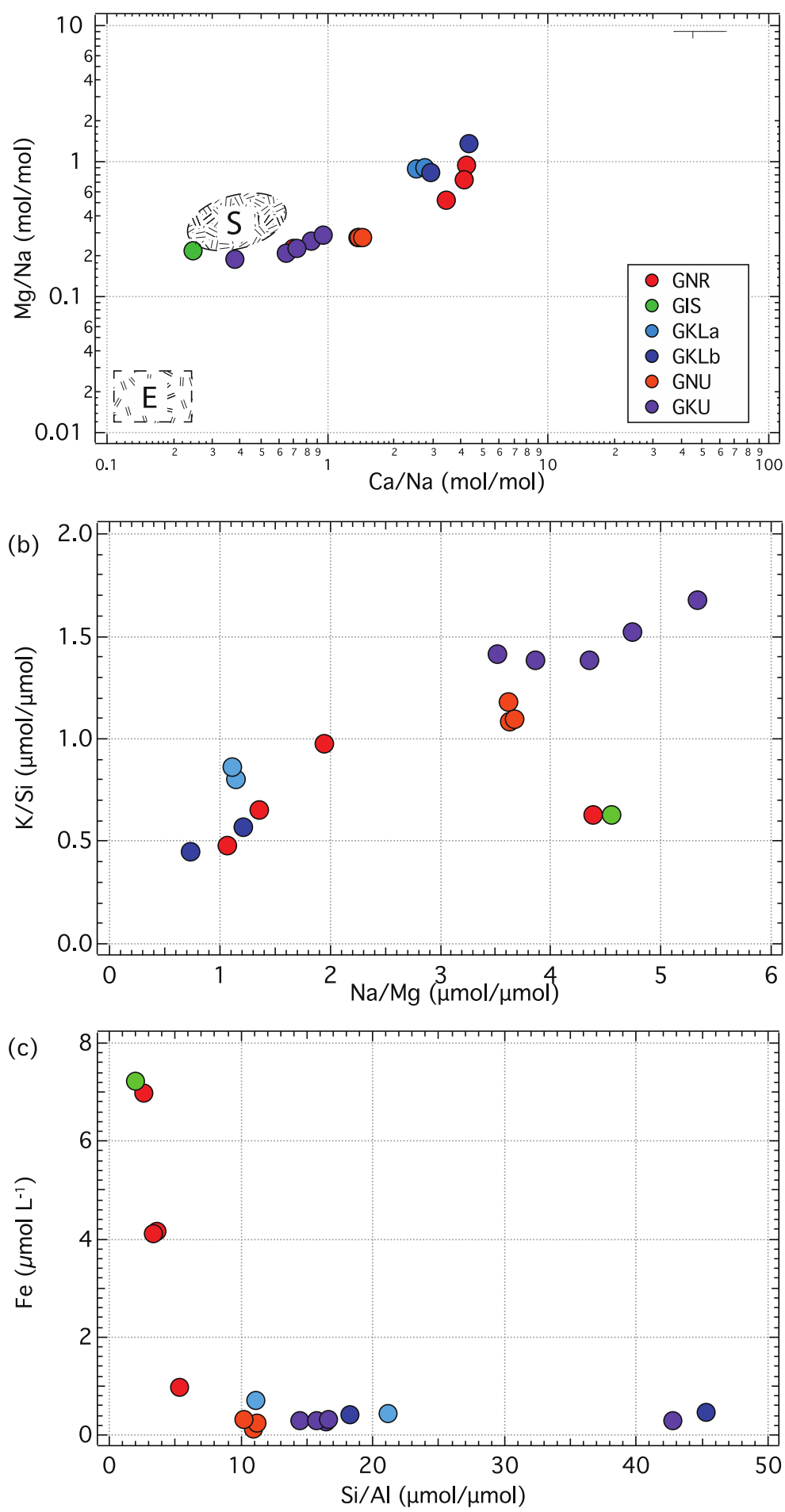

Figure 3: Elemental concentrations from the dissolved loads of the bulk subglacial outflows (a) K/Si versus $\mathrm{Na} / \mathrm{Mg}$, all samples have highly elevated $\mathrm{K} / \mathrm{Si}$ ratios. Outflows from the RG trend towards more mafic endmembers, while the GG trends towards more felsic. (b) $(\mathrm{Mg} / \mathrm{Na}$ versus $\mathrm{Ca} / \mathrm{Na}), \mathrm{E}=$ evaporate range, $\mathrm{S}=$ silicate range, and $\mathrm{C}=$ carbonate range in major rivers as defined in Gaillardet et al. (1999). (c) Fe versus $\mathrm{Si} / \mathrm{Al}$, subglacial outflows with a higher Fe concentration may have a relatively higher clay content than those with lower Fe concentrations 
that suggests that pyrite oxidation may be the dominant source of Fe. Given that the Fe isotopic composition of dissolved $\mathrm{Fe}$ in the GNR outflow is not distinct from that of suspended sediment (Table 1), this suggests that pyrite oxidation alone does not drive the low $\delta^{56} \mathrm{Fe}$ values. At the other end of the spectrum is the GKU outflow, which has a low $\mathrm{Fe} / \mathrm{S}(<0.02)$ and a dissolved $\mathrm{Fe} \delta^{56} \mathrm{Fe}$ value that is substantially lower than that of the suspended sediments. Again, this suggests that sources or processes other than pyrite dissolution generate low $\delta^{56} \mathrm{Fe}$ values in outflow. Where it occurs, sulphide oxidation is likely linked to carbonate dissolution due to the relatively rapid dissolution kinetics of carbonates at lower pH (Eqn. 4; Wadham et al., 2013). As waters subsequently become saturated with respect to carbonate, or carbonate minerals are exhausted, pyrite oxidation may promote silicate dissolution, (Eqns. 3 and 4; from Wadham et al., 2013), and thus promote Fe release from silicate minerals such as biotite or chlorite:

$$
\begin{aligned}
& 4 \mathrm{FeS}_{2(\mathrm{~s})}+16 \mathrm{Ca}_{1-\mathrm{x}}(\mathrm{Mg})_{\mathrm{x}} \mathrm{CO}_{3(\mathrm{~s})}+15 \mathrm{O}_{2(\mathrm{aq})}+14 \mathrm{H}_{2} \mathrm{O}_{(\mathrm{l})} \longleftrightarrow 16_{(1-\mathrm{x})} \mathrm{Ca}^{2+}{ }_{(\mathrm{aq})}+16 \mathrm{Mg}^{2+}{ }_{\text {(aq })}+16 \mathrm{HCO}_{3}^{-} \\
& { }_{(\mathrm{aq})}+8 \mathrm{SO}_{4}{ }^{2-}{ }_{(\mathrm{aq})}+4 \mathrm{Fe}(\mathrm{OH})_{3(\mathrm{~s})} \\
& 4 \mathrm{FeS}_{2(\mathrm{~s})}+16 \mathrm{Na}_{1-\mathrm{x}} \mathrm{K}_{\mathrm{x}} \mathrm{AlSi}_{3} \mathrm{O}_{8(\mathrm{~s})}+15 \mathrm{O}_{2(\mathrm{aq})}+86 \mathrm{H}_{2} \mathrm{O}_{(\mathrm{l})} \longleftrightarrow 16_{(1-\mathrm{x})} \mathrm{Na}^{+}{ }_{(\mathrm{aq})}+16 \mathrm{~K}_{(\mathrm{aq})}^{+}+8 \mathrm{SO}_{4}^{{ }_{-}^{2-}}{ }_{\text {(aq) }}+ \\
& 4 \mathrm{Al}_{4} \mathrm{Si}_{4} \mathrm{O}_{10}(\mathrm{OH})_{8(\mathrm{~s})}+32 \mathrm{H}_{4} \mathrm{SiO}_{4(\mathrm{aq})}+4 \mathrm{Fe}(\mathrm{OH})_{3(\mathrm{~s})}
\end{aligned}
$$

The proportion of $\mathrm{HCO}_{3}{ }^{-}$derived from sulphide oxidation coupled with carbonate dissolution relative to other sources of $\mathrm{HCO}_{3}^{-}$(i.e., silicate weathering) may be crudely estimated by considering the sulphate mass fraction $\left(\mathrm{SMF}, \mathrm{SMF}=\mathrm{SO}_{4}{ }^{2-} /\left(\mathrm{SO}_{4}{ }^{2-}+\mathrm{HCO}_{3}{ }^{-}\right)\right.$; Tranter et al., 2002). In waters in which coupled sulphide oxidation and carbonate dissolution dominates, SMF equals 0.5. Increased carbonate dissolution relative to sulphide oxidation drives waters to $\mathrm{SMF}$ values $<0.5$, while sulphide oxidation coupled to silicate weathering will drive waters $>0.5$ due to subglacial precipitation of carbonates (Tranter et al., 2002). For the GNR, GKL, and GNU outflows, SMF values range from 0.1 to 0.3 , indicating that carbonate dissolution is the dominant source of $\mathrm{HCO}_{3}{ }^{-}$, which is also supported by their $\mathrm{Ca} / \mathrm{Na}: \mathrm{Mg} / \mathrm{Na}$ compositions (Fig 3 (a)). In regions of the GIS underlain by banded iron formations (BIFs; e.g., the Isua Supracrustal Belt in southwest Greenland), metacarbonates in BIFs have been shown to have low $\delta^{56} \mathrm{Fe}$ values (e.g. Dauphas et al., 2007) that may impact the $\delta^{56} \mathrm{Fe}$ of the dissolved load. The GKU outflows have SMF values ranging from 0.3 to 0.53 , suggesting in the context of the SFM, sulphide oxidation is linked to carbonate dissolution. The GIL outflow has a SMF value of $\sim 0.8$, nevertheless, the GIL has a very high sulphate concentration, which may be from a marine origin (or a potential evaporate end member, see also Fig 3 (a)), as discussed previously.

In summary, the major element chemistry supports the notion that silicate weathering dominates outflow chemistry, with some input from sulfide oxidation and carbonate dissolution. Iron concentrations correlate with $\mathrm{Si} / \mathrm{Al}$ in the sampled streams (Fig. 3c), suggesting higher $\mathrm{Fe}$ concentrations in congruently weathering systems and lower Fe concentrations in incongruently 
weathering systems; in the latter case, Fe is likely to be immobilized as secondary phases in the subglacial environment. The observed geochemical trends may also be a function of water-rock interaction times within the glacial system. In particular for the GKL outflows, hydrochemical measurements have indicated that water-rock contact times at this location are much shorter than for the other outflows (GNU, GNR and GKU; Aciego et al., 2015). However, one would expect short water-rock interaction times to be associated with congruent weathering whereas incongruent weathering may be expected where water-rock interaction time increases, and secondary minerals reach saturation. Therefore, we interpret the hydrochemical data in terms of the extent to which weathering has occurred in subglacial systems. In the following sections, we use the term "incipient weathering" to denote processes that occur early in the weathering process, and explore the mechanisms and/or processes that explain the Fe isotope data from the standpoint of incipient weathering.

\subsection{The Fe isotopic composition of subglacial outflows draining the Greenland Ice Sheet}

\subsubsection{The $\delta^{56} \mathrm{Fe}$ composition of subglacial stream sediments}

The suspended sediment $\delta^{56} \mathrm{Fe}$ values lie within previously published measurements of stream suspended sediments (e.g. Bergquist and Boyle, 2006; Fantle and DePaolo, 2004), as well as igneous rocks from SW Greenland (Akilia; $0.03 \pm 0.12 \%$, (Dauphas et al., 2004) and the crustal array (Beard and Johnson, 2004; Poitrasson, 2006). At the GNU, GIL and GNR outflows there is little significant difference between the $\delta^{56} \mathrm{Fe}$ of suspended sediments and the dissolved loads (Fig. 2), a feature that is also observed in glacially fed rivers such as the Copper River in Alaska (Escoube et al., 2015; Schroth et al., 2011). This observation agrees with previous $\delta^{56} \mathrm{Fe}$ measurements in glacial outflow from Bayelva River near Kongsfjorden Svalbard (500 m downstream of the terminus; Zhang et al., 2015). The measured $\delta^{56} \mathrm{Fe}$ values in the Bayleva River exhibit low variability $(\sim 0 \% \pm \pm 0.1 \%)$, which are similar to range of $\delta^{56} \mathrm{Fe}$ values in outflows from the GNU, GIL and GNR, have been interpreted to reflect the isotopic composition of particles and colloids derived directly from physical erosion (i.e., not the dissolved fraction).

The mineralogy of silt and the finer material (suspended sediments) produced through physical erosion in glacial environments is generally thought to reflect the mineralogy of the bulk bedrock (Anderson, 2005). By extension, one can argue that the $\delta^{56} \mathrm{Fe}$ of suspended sediments in glacial settings should also reflect the $\delta^{56} \mathrm{Fe}$ of the bedrock. If this is true, then we expect that the $\delta^{56} \mathrm{Fe}$ of the weathering bedrock to be $\sim 0 \%$ (i.e., similar to average crustal $\delta^{56} \mathrm{Fe}$ values). This suggests that glacial rivers characterized by near crustal $\delta^{56} \mathrm{Fe}$ values should mainly reflect the contribution of colloids and particles derived from physical erosion, assuming minimal isotopic fractionation 
(Escoube et al., 2015). Subsequently, if isotopic variability in source is not a reasonable means of explaining the Fe isotopic composition of the dissolved load, then a process (or processes) must determine the $\delta^{56} \mathrm{Fe}$ of the dissolved load to $\delta^{56} \mathrm{Fe}$ values as much as $-2.1 \%$ relative to the suspended sediments.

\subsubsection{Controls on the Fe isotopic composition of dissolved Fe in subglacial streams}

The simplest observations that can be made with respect to the $\delta^{56} \mathrm{Fe}$ values of dissolved Fe in Greenland Ice Sheet outflows are that they are spatially variable, are typically lower than local suspended sediment (DL average $\sim-0.7 \%$; SS average $\sim 0 \%$ ), and do not correlate with $\mathrm{Fe}$ concentration (Fig. 4a). The average $\delta^{56} \mathrm{Fe}$ of the dissolved load in Greenland is comparable to the dissolved loads $(<0.45 \mu \mathrm{m})$ of tropical, temperate, and Arctic river waters (e.g., Bergquist and Boyle, (2006), Fantle and DePaolo, (2004) and Escoube et al. (2015), respectively), which range from about -1.2 to $2.5 \%$, but the lowest $\delta^{56} \mathrm{Fe}$ values $(-2.1 \%$ ) in GIS outflow are lighter than such riverine values. The lowest $\delta^{56} \mathrm{Fe}$ measured in Arctic rivers to date $(-1.7 \%)$ occurs in the $<0.1 \mu \mathrm{m}$ to $<1 \mathrm{kD}$ size fraction of small organic-rich arctic rivers (Escoube et al., 2015; Ilina et al., 2013)). Glacial ouflows are not organic rich compared with riverine systems, with dissolved organic carbon concentrations typically on the order of $0.32 \mathrm{mg} \mathrm{L}^{-1}$ (Bhatia et al., 2013b). Given the variability in dissolved $\delta^{56} \mathrm{Fe}$ in GIS outflows, and in some cases highly negative $\delta^{56} \mathrm{Fe}$ compositions, there must be another process (or processes) that occurs in the subglacial environment that explains the observed variability in outflow $\delta^{56} \mathrm{Fe}$.

Understanding the mechanistic controls on the Fe isotopic composition of natural reservoirs (e.g., soil, rivers, groundwater) is vital to the development of the Fe isotope proxy, the successful use of which relies on a clear mechanistic understanding of the isotopic fractionation that occurs as $\mathrm{Fe}$ moves from reservoir to reservoir within the global Fe cycle. The most simple and straightforward hypotheses are that the $\delta^{56} \mathrm{Fe}$ of dissolved $\mathrm{Fe}$ is controlled by redox-related speciation effects, $\mathrm{Fe}$ (oxy)hydroxide precipitation, or incipient mineral dissolution. With respect to redox-related isotope effects, the most significant isotopic fractionation in the Fe system that between aqueous ferrous (Fe(II)) and ferric iron ( $\mathrm{Fe}(\mathrm{III})$ ); at $0^{\circ} \mathrm{C}$, aqueous $\mathrm{Fe}(\mathrm{II})$ and $\mathrm{Fe}(\mathrm{III})$ are different by $-3.6 \%$ (Welch et al., 2003), which encompasses the large $\delta^{56} \mathrm{Fe}$ range in GIS glacial outflows. In a closed system at isotopic equilibrium, the Fe isotopic composition of the $\mathrm{Fe}(\mathrm{III})$ component $\left(\delta_{I I I}\right)$ is constrained by the fractionation factor between aqeuous $\mathrm{Fe}(\mathrm{II})$ and $\mathrm{Fe}(\mathrm{III})\left(\Delta_{I I-I I I}\right)$ and the $\mathrm{Fe}(\mathrm{III}): \mathrm{Fe}(\mathrm{II})$ ratio $\left(N_{I I I} / N_{I I}\right)$.

$$
\delta_{I I I}=\delta_{\text {system }}-\frac{\Delta_{I I-I I I}}{1+\frac{N_{I I I}}{N_{I I}}}
$$


Consequently, the isotopic composition of the dominant Fe(III) species in oxygenated systems will reflect the source material while $\mathrm{Fe}$ (II) will be fractionated by as much as $-3.6 \%$ at $0^{\circ} \mathrm{C}$. Conversely, in reducing systems (low $N_{I I I} / N_{I I}$ ), the Fe(II) species will be dominant and will therefore reflect the source, while Fe(III) will be fractionated by as much as $3.6 \%$ relative to the source. In between these two redox extremes, and assuming a system closed to external mass exchange, the $\delta^{56} \mathrm{Fe}$ of each species will vary in accordance with their relative abundances.

This simple logic leads to the initial hypothesis that low $\delta^{56} \mathrm{Fe}$ values in glacial outflows reflect more oxidizing subglacial environments, while $\delta^{56} \mathrm{Fe}$ values close to $0 \%$ reflect more reducing conditions. This hypothesis assumes that our measurements primarily reflect $\mathrm{Fe}(\mathrm{II})$, and that $\mathrm{Fe}(\mathrm{II})$ and $\mathrm{Fe}$ (III) are separated quickly and effectively in the subglacial environment (assuming no repeated cycling or back-reaction) via Fe-(oxy)hydroxides precipitation and/or adsorption onto mineral surfaces (Bullen et al., 2001; Welch et al., 2003; Mikutta et al., 2009). While it is difficult to assess this hypothesis, the $\mathrm{pH}$ data (and calculated Eh values) from each site indicates that the subglacial streams are firmly in the hematite/ferrihydrite field on an iron Eh-pH diagram (Fig. 4b). The redox boundary may shift depending on the concentration of $\mathrm{Fe}$ in the water (Fig. 4b), which is an important consideration to take into account when interpreting glacial outflow waters with a considerable range in Fe concentrations. While all subglacial GIS waters are calculated to be oxidized, the most fractionated GKL waters plot closer to the $\mathrm{Fe}^{2+}-\mathrm{Fe}(\mathrm{OH})_{3}$ boundary, while less fractionated waters plot farther from the boundary. If we assume that waters closer to the boundary have a greater proportion of $\mathrm{Fe}(\mathrm{II})$, and that the isotopic composition of the total $\mathrm{Fe}$ in each glacial outflow is similar, then we would expect the GKL dissolved load to have higher, and not lower, $\delta^{56} \mathrm{Fe}$ values. Thus, this simple hypothesis does not, on its own, account for what we see in subglacial waters.

However, we cannot conclusively rule out a role for redox-related speciation effects in controlling outflow $\delta^{56} \mathrm{Fe}$, specifically oxidation and precipitation of $\mathrm{Fe}$ in subglacial systems. Equilibrium thermodynamic modeling using PHREEQC (Parkhurst and Appelo, 1999) suggests that mineral saturation indices of outflow across the Greenland Ice Sheet vary between outflows (Aciego et al., 2015). In particular for Fe-oxides (highlighted in Fig 4c) the majority of the outflows are supersaturated in ferrihydrite, goethite, and hematite. The exceptions to this are the outflows from GKL, which are inferred to be below (and not at) ferrihydrite saturation. This suggests that GKL represents the most pristine $\mathrm{Fe}$ isotopic signal related to the release of $\mathrm{Fe}$ in the subglacial weathering environment, most like a consequence of shorter residence times and water-rock contact times. Precipitation of Fe-oxides during subglacial stream processing provides a mechanism for the removal of Fe from the dissolved load and thus a means by which to fractionate Fe isotopically (e.g. Johnson et al., 2008). Ultimately, this aspect remains difficult to assess with the data we have presented herein, but warrants further investigation. 

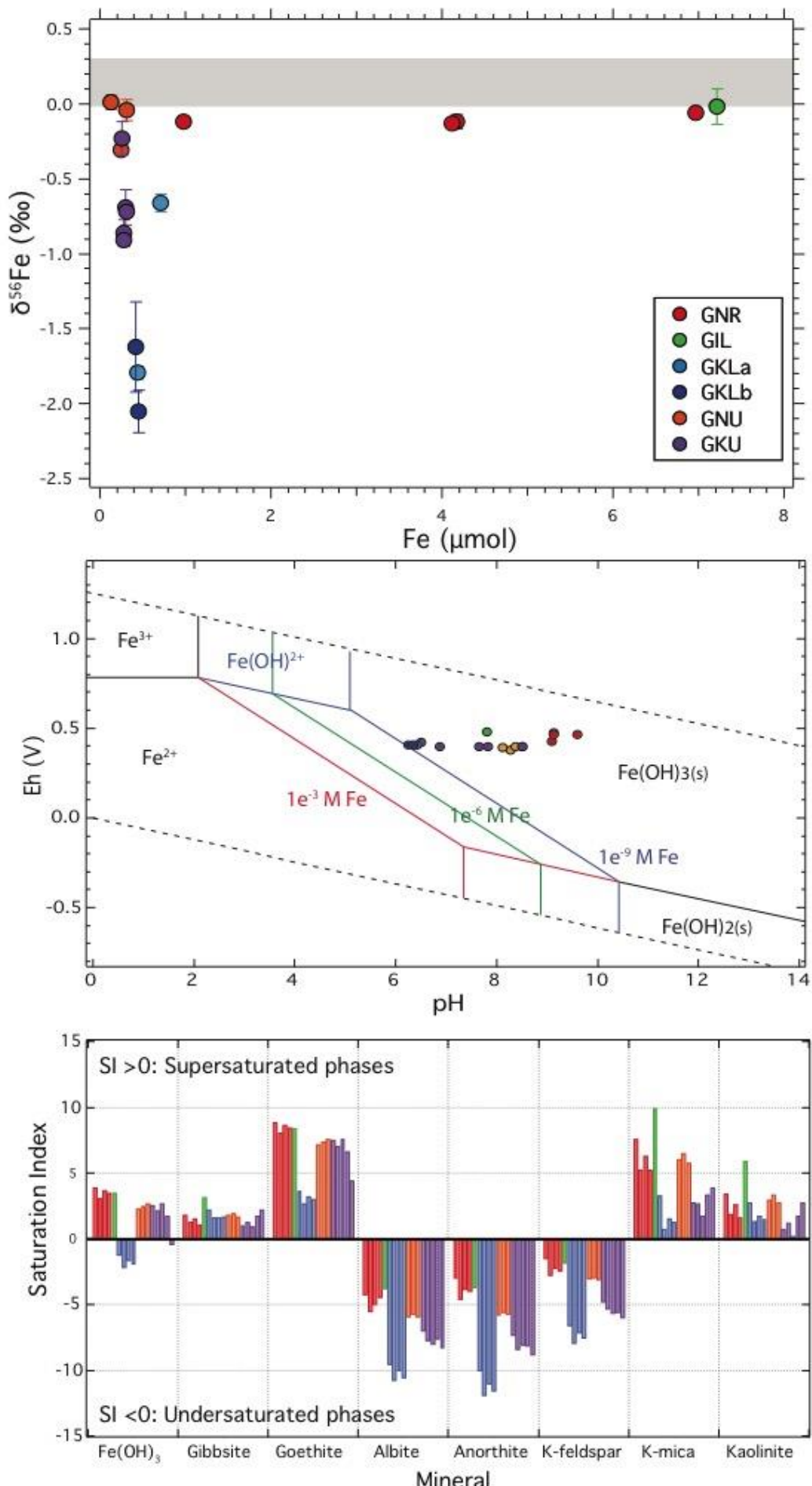

Figure 4: (a) Total dissolved $(<0.2 \mu \mathrm{m}) \mathrm{Fe}$ concentration versus $\delta^{56} \mathrm{Fe}(\%)$. Grey bar represents a broad modern crustal (mafic) array (Poitrasson, 2006). (b) Eh-pH stability diagram for Fe. The upper and lover dotted lines represent the equilibrium between water and oxygen gas, while the solid black lines show the range of $\mathrm{Fe}$ speciation given set $\mathrm{pH}$ and Eh ranges. Red, green and blue lines represent $\mathrm{Fe}$ concentrations of $1 \cdot 10^{-3}, 1 \cdot 10^{-6}$ and $1 \cdot 10^{-9} \mathrm{M}$ Fe respectively. (c) PHREEQC modeling, not all predicted minerals shown, data from Aciego et al. (2015) with the exception of the SQS, which was modeled for this manuscript, see Supplementary Information.

The PHREEQC modeling also indicates that all meltwaters are undersaturated in primary silicates (i.e., albite, anorthite, and K-feldspar), calcite and aragonite, and pyrite (see Table 3 in 
Aciego et al., 2015), and saturated with respect to Fe-oxyhydroxide, hematite, and goethite (Fig. 4c, with the exception is the RG outflow, discussed above which is undersaturated in ferrihydrite). This suggests that, insofar as outflow reflects the subglacial environment, primary silicate and pyrite dissolution, as well as secondary oxide precipitation, control the Fe isotopic composition of outflow. An alternate hypothesis therefore is that silicate weathering processes, which have been associated with large kinetic isotope effects (e.g. Kiczka et al., 2010), may explain the observed variation in outflow $\delta^{56} \mathrm{Fe}$. As discussed in Section 4.1, there is a wealth of geochemical evidence relates outflow $\delta^{56} \mathrm{Fe}$ to the major element chemistry, which is explored below.

\subsubsection{Influence of incipient weathering on the $\delta^{56} \mathrm{Fe}$ of dissolved Fe in the subglacial environment}

The Fe isotopic composition of subglacial streams is controlled by physical and chemical weathering processes that release and sequester $\mathrm{Fe}$ in the subglacial weathering environment. Such processes include the dissolution of primary phases such as silicates and pyrite, oxic and anoxic weathering, and the formation of secondary minerals. Previously, the isotopic composition of dissolved Fe in glacial outflows has been linked to the weathering of Fe(II)-rich silicate minerals, such as biotite, hornblende, and chlorite (Crusius et al., 2011; Kiczka et al., 2010; Kiczka et al., 2011; Schroth et al., 2011; Schroth et al., 2014). Additional non-redox chemical changes in Fe speciation have also been associated with large kinetic isotope effects (Zhang et al., 2015) for example during inorganic $\mathrm{Fe}(\mathrm{III})$ precipitation experiments $\delta^{56} \mathrm{Fe}$ ranged from $-0.22 \%$ to $-2.12 \%$ (Balci et al., 2006). Laboratory dissolution experiments (both biotic and abiotic) of mineral separates and soils have typically shown that Fe in solution is initially isotopically lighter than the bulk mineral by up to $1.8 \%$ (e.g., Brantley et al., 2004; Chapman et al., 2009; Kiczka et al., 2010)). This is typically followed by a gradual transition towards less fractionated values with increased $\mathrm{Fe}$ release from the mineral structure. Additional studies have suggested isotope effects observed in the field are a consequence of mixing between Fe pools with different isotopic compositions (e.g., Chapman et al., 2009) and/or kinetic isotope effects associated with the formation of leached surface layers, non-steady state dissolution, and the action of bacteria/organic ligands (e.g., Brantley et al., 2004; Kiczka et al., 2010; Wiederhold et al., 2006). Potentially, some or all of these process may contribute to the bulk dissolved load $\delta^{56} \mathrm{Fe}$ composition.

There is evidence in the literature that the $\mathrm{Fe}$ isotopic fractionation associated with silicate dissolution, in particular phyllosilicate dissolution, is considerable. For example, Kiczka et al. (2010) investigated the $\mathrm{Fe}$ isotopic effects associated with the dissolution of phyllosilicate mineral separates (such as biotite) under anoxic conditions. They found the lowest $\delta^{56} \mathrm{Fe}$ values in the dissolved load ( -1.2\%) compared to the mineral $(\sim 0.3 \%$ o) were generated during the initial stages of mineral dissolution. Kinetic isotopic fractionation factors as low as $-2.0 \%$ associated with proton-promoted 
dissolution explained the early stage fractionation of the Kiczka et al., (2010) dissolution experiments; a similar isotope effect may also explain the dissolved load $\delta^{56} \mathrm{Fe}$ in the GKL and GKU outflows. If we assume a simple view of a weathering mineral, namely that a dissolution proceeds uniformly from the solution-mineral interface into the crystal, such a mechanism becomes complicated. In theory, if the $\mathrm{Fe}$ at a dissolving mineral surface is isotopically fractionated during dissolution, then the dissolving surface will be isotopically distilled; subsequent dissolution will release the distilled $\mathrm{Fe}$ from the surface. Ultimately, then, over time scales that are relevant to natural systems, the isotopic composition of the cumulative $\mathrm{Fe}$ released to solution will reflect that of the bulk mineral. Interestingly, Kiczka et al. (2010; 2011) suggested (based on experimental observations) that exfoliation processes in phyllosilicates can continually expose new surfaces to dissolution, such that the isotopic signal of dissolving distilled surfaces is not fully expressed. In an analogous manner, we can tentatively suggest that given the high rates of mechanical crushing and abrasion in subglacial systems may continually expose fresh mineral surfaces, which incipiently weather over short time scales without the expression of significant distillation effects. Accordingly, the Fe isotopic composition of the dissolved load in Greenland can be explained by isotopic fractionation associated with incipient silicate mineral dissolution (i.e., the early stages of chemical weathering), such that isotopically light $\mathrm{Fe}$ is preferentially released and transported in glacial outflow.

It should be stressed that the most isotopically fractionated Fe occurs in GKL outflow, which is inferred to be the only one of those sampled that is below ferrihydrite saturation. This then suggests that GKL represents a "near pristine" Fe isotopic signal related to the release of Fe by incipient silicate weathering from the subglacial environment. In the GKL outflow, two marginal outlets that drain the same glacial region (Fig. 1d) have similar $\delta^{56} \mathrm{Fe}$ values, suggesting similar subglacial geochemical processing of $\mathrm{Fe}$ within a given glacial system. Likewise, the suggestion of a pristine incipient silicate signal in GKL outflow is supported by the thermodynamic constraints on saturation state and the elemental data in Section 4.2.2. In the other outflows where the $\delta^{56} \mathrm{Fe}$ of the dissolved load is similar to the suspended sediment (GNR, GNU and GIL), Fe concentrations and ionic strengths are relatively higher, as are total alkalinities (Aciego et al. (2015), Table 1). At the same time, molar Si/Al ratios in these waters are at the low end of the range measured (Fig. 3c), and approach values of 2-3 that are most likely explained by congruent silicate weathering. Therefore, based on the major element chemistry, we hypothesize that weathering at Sites GKL and GKU is dominated by incongruent silicate weathering, which is characterized by high $\mathrm{Si} / \mathrm{Al}$ ratios, low ionic strengths, circumneutral $\mathrm{pH}$ $(\sim 6.5)$, and low total alkalinities.

This hypothesis is also consistent with the observed relationship between the ionic strength of outflow and the $\delta^{56} \mathrm{Fe}$ value (Fig. 5). At low ionic strengths characteristic of incipient, incongruent chemical weathering, outflow $\delta^{56} \mathrm{Fe}$ values are low, while at higher ionic strengths (i.e., more extensively weathered), outflow $\delta^{56} \mathrm{Fe}$ values are similar to coexisting suspended sediment. However, 
such a correlation is not explained by simple meltwater dilution. This hypothesis also requires that there may an isotopically heavy reservoir somewhere in the system, either retained in the subglacial setting or in the stream, which we have not measured in any of the outflows. If there is an isotopically heavy Fe reservoir in the sediments of the most fractionated streams (GKL, GKU) which we do not measure in the suspended sediment from these outflows, this may be explained many ways (which we do not have the data to evaluate at present) including: (i) the retention of distilled phases in the subglacial domain, (ii) overprinting of the isotope effect (e.g., through secondary mineral formation), and (iii) mass balance arguments by which the residual $\mathrm{Fe}$ has not been distilled to a detectable amount and/or has been diluted by other Fe sources (e.g., from less soluble primary phases).

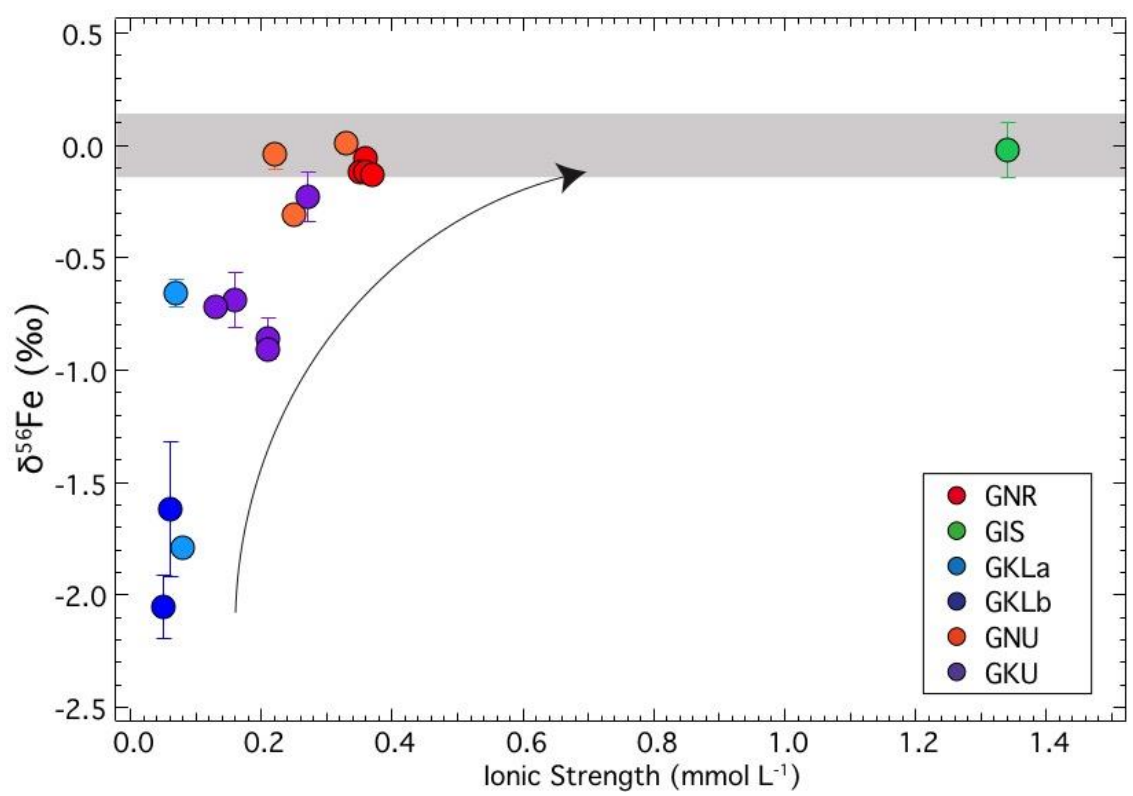

Figure 5: Variation of ionic strength with $\delta^{56} \mathrm{Fe}(\%)$. Ionic strength calculated from major element and anion concentrations, see Table 1. Grey bar represents a broad modern crustal (mafic) array (Poitrasson, 2006).

The hypothesis presented above certainly requires further development, and in particular our spot sampling regime may not be representative of average glacial outflow conditions. The meltwater flux from glaciers undergoes significant seasonal variation, and potentially the hydrological network beneath each glacier may vary in length scale and distribution, and thus water:rock contact times, and the proportions of hydrological end-members will vary (e.g. snow and ice) throughout a melt season. In addition both within and between glacial settings the subglacial microbial communities may differ significantly, impacting biotic weathering process, and potentially redox state. For instance, it is well established that microorganisms are active in subglacial systems (Boetius et al., 2015), and can dynamically cycle Fe via microbially mediated chemical reactions, at a variety of redox conditions (e.g. Bottrell and Tranter, 2002; Wadham et al., 2004; Wadham et al., 2010a; Wadham et al., 2010b; Wynn et al., 2006) that can fractionate Fe isotopically (e.g., during dissimilatory iron reduction; Percak-Dennett et al., 2011). Biotic chemical weathering in its extreme is evident in the subglacial ferrous 'ocean' of Blood Falls, a subglacial outflow from the Taylor Glacier on the East Antarctic Ice 
Sheet (Mikucki et al., 2009). This oxygen-free environment is rich in sulfate and Fe(II), the latter of which is liberated from subglacial bedrock minerals under anoxic conditions by microbial activity, resulting in dissolved $\mathrm{Fe}$ that has $\delta^{56} \mathrm{Fe}$ values of $-2.60 \pm 0.5 \%$ (Mikucki et al., 2009). The low $\delta^{56} \mathrm{Fe}$ values at Blood Falls are inferred to be a consequence of microbial redox cycling and dissimilatory iron reduction. Whilst this is a process we are not able to sufficiently assess with the data presented here, the $\delta^{56} \mathrm{Fe}$ values of dissolved $\mathrm{Fe}$ at GKL (as low as $-2.1 \%$ ) are at least consistent with a control by redox processing. Repeated cycles of reductive dissolution and/or partial oxidation caused by microbial action may generate significant differences in isotopic composition of the dissolved loads of subglacial outflows, and warrants further investigation. A seasonal investigation of the evolution of $\delta^{56} \mathrm{Fe}$ in both suspended sediments and dissolved loads, as well as microbial diversity is also necessary in order to place further constraints on glacial outflow $\delta^{56} \mathrm{Fe}$ variability and evolution.

\subsection{Comments on the dissolved Fe flux and $\delta^{56} \mathrm{Fe}$ from the Greenland ice sheet}

Ultimately, the work presented herein suggests that subglacial runoff from some large land terminating glaciers draining the GIS are sources of isotopically light dissolved Fe. Given the high erosion rates and subsequent generation of highly reactive sediments, its possible a light signal may be maintained as a glacial end-member. But whether or not that signal can be maintained downstream is questionable, especially given that the most fractionated outflows have the lowest Fe concentrations. Processing in proglacial environments and estuaries will have a significant impact on the dissolved Fe fluxes, $\mathrm{Fe}$ speciation, and the removal of $\mathrm{Fe}$ via flocculation and other secondary weathering processes. Zhang et al. (2015) suggest that during esturine processing there is little fractionation of the $\delta^{56} \mathrm{Fe}$ composition of dissolved loads from glacial outflows, whereby $\mathrm{Fe}$ is lost from the dissolved phase by a process that fractionates $\delta^{56} \mathrm{Fe}$ by less than $0.05 \%$. But this study also reported little total iron isotope variation in the upstream glacial end-member $(\sim \pm 0.1 \%)$ compared to the large variation reported here. The lightest composition in this study was also undersaturated in ferrihydrite phases (GKL, Fig. 4), therefore the inevitable precipitation of such phases downstream as a result of oxidation with undoubtedly alter the $\delta^{56} \mathrm{Fe}$ composition of this dissolved load. Future analysis of downstream transects may elucidate the fate of such isotopically light dissolved Fe.

Meltwater fluxes from the GIS to the ocean are not uniform, as various drainage basins have different responses to regional and global climate change (e.g. Lewis and Smith, 2009; Rignot, 2011; Sasgen et al., 2012). Iron concentrations vary by an order of magnitude between the glacial outflows measured here (from $\sim 0.1$ to $7 \mu \mathrm{M} \mathrm{L}^{-1}$ ), meaning that regional differences in Fe fluxes to the coastal ocean are a function of geographical location. Assuming that the average concentration of each sampled glacial outflow represents all outflows within a given geographical region (where the regions are defined as in Lewis and Smith (2009); Table 2), we estimate the flux of dissolved Fe exported 
from the GIS. We used the meltwater flux estimates from Lewis and Smith (2009), which are a reasonable approach for this initial estimate of Fe fluxes. The meltwater flux estimates from Lewis and Smith (2009) are based on the locations of 460 meltwater outlets (proglacial lakes, streams, and rivers; and sediment plumes into fjords) mapped along the ice sheet perimeter, this is important so that our flux estimates refer to land terminating glaciers and not to ocean terminating glaciers, which were not sampled. Where we do not have dissolved Fe concentration data from a given region (i.e., from regions in the north; Table 2), we use the average mean Fe concentration from our measured glacial outflows $\left(1.61 \mu \mathrm{mol} \mathrm{L}{ }^{-1}\right)$ to broadly estimate the Fe flux from these regions.

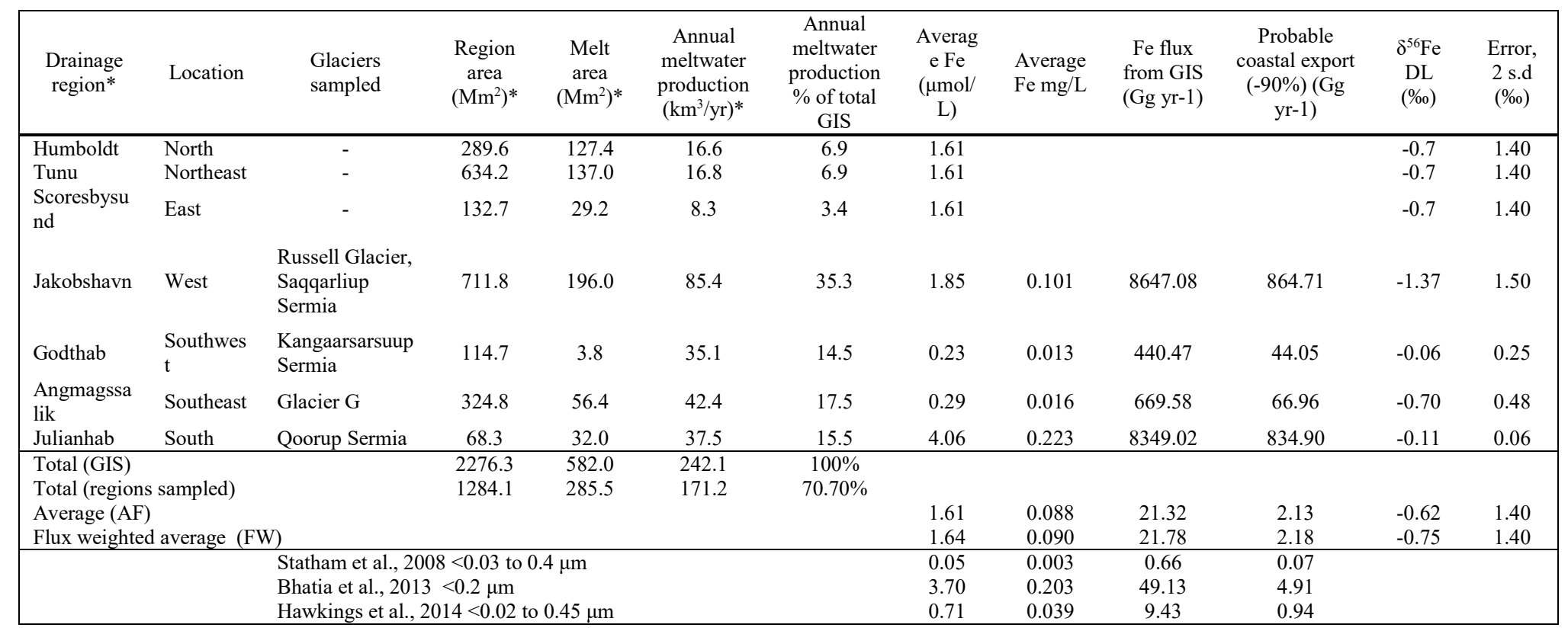

686

Table 2: Simple model calculations for determining the dissolved load Fe flux from different regions draining the GIS. Hydrological data (*) is from Lewis and Smith, (2009). Previous measurements of dissolved load concentration data are shown for Bhatia et al., (2013a), Hawkings et al., (2014) and Statham et al., (2008). AF is average flux, FW is the flux normalized data for each draining region. Dissolved Fe concentrations for the Humboldt, Tunu and Scoresbysund regions are the average Fe concentrations calculated from all the outflows.

Using these regional concentration estimates, we calculate the average (AF), and flux weighted average (FW) concentration of Fe in GIS meltwaters. The resulting AF is $1.61 \mu \mathrm{mol} \mathrm{L} \mathrm{L}^{-1}$, while $\mathrm{FW}$ is $1.64 \mu \mathrm{mol} \mathrm{L}{ }^{-1}$. For each of these flux estimates (AF and FW), we calculate a total $\mathrm{Fe}$ export from the entire GIS ( $\mathrm{Gg} \mathrm{Fe} \mathrm{yr}^{-1}$, Table 2). Given that there is a significant loss of Fe from the dissolved load during transport through estuarine environments, we have further calculated a

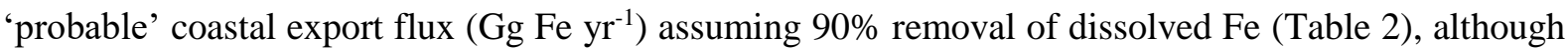
we recognize it may be as high as $99 \%$. For comparison, we also recalculate the dissolved load $(<0.45$ $\mu \mathrm{m}) \mathrm{Fe}$ fluxes from Bhatia et al. (2013a), Statham et al. (2008), and Hawkings et al. (2014), using the AF model, then similarly assume a $90 \%$ estuarine removal (Table 2). The results of our simple calculations, which are independent of Fe isotopes, suggest a total dissolved Fe flux from GIS glaciers

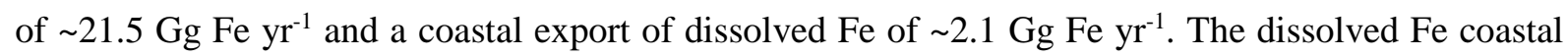




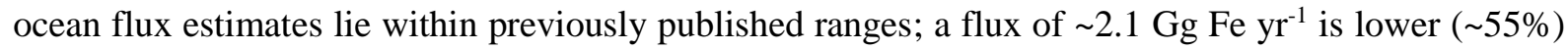
than that of the recalculated dissolved load fluxes (Table 2) from Bhatia et al. (2013a), and double those of Hawkings et al. (2014). Our calculated Fe flux is much lower than the global riverine input (0.14 Tg Fe $\mathrm{yr}^{-1}$; Raiswell and Canfield, 2012), and lower than the modern aeolian dust flux to the

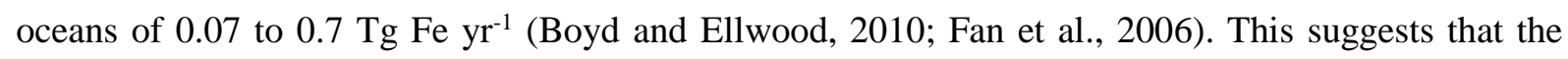
'dissolved' flux of Fe from the GIS is not globally significant, consistent with the conclusions of Hopwood et al. (2015) and Zhang et al. (2015). It is noteworthy that our flux estimate does not include either the contribution of labile Fe from glacial sediments or particulates $>0.2 \mu \mathrm{m}$, which are the most significant source of labile Fe in meltwaters (e.g. Bhatia et al., 2013a; Hawkings et al., 2014). Our spot sampling approach does not allow us to calculate a catchment area normalized dissolved load flux, as the effective catchment area depends on how much melting takes place in a given melt-season (Hindshaw, 2014). Additionally, we did not measure Fe concentrations over the entire melt season at each glacier, therefore this estimate does not account for temporal variability in outflow $\mathrm{Fe}$ concentrations during the melt season. However, by sampling at peak melt when glacial meltwater is most dilute, our calculations may represent a minimum flux (Aciego et al., 2015).

\section{Conclusions}

In this contribution, we present the first evidence of significant Fe isotopic fractionation in the dissolved load of subglacial streams draining land-terminating glaciers in Greenland. Such a discovery is significant, as it highlights that dissolved Fe generated within subglacial systems can be driven to extremely light $\delta^{56} \mathrm{Fe}$ compositions $\left(-2.1 \%\right.$ ), and that variability in dissolved $\delta^{56} \mathrm{Fe}$ is highly dependent on individual glacial systems. Simple calculations suggest that the dissolved load Fe flux from GIS

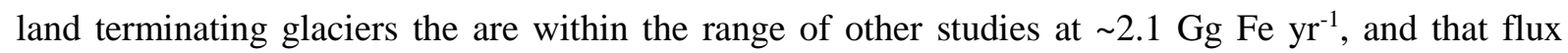
weighted calculations based on regional melt water estimates produce a similar flux to those extrapolated from a single region. Nevertheless, the diversity in the range of Fe concentrations and $\delta^{56} \mathrm{Fe}$ compositions from individual outlets highlights the importance of ascertaining geographically distributed hydrochemical data sets for glacial systems.

Suspended sediments have a relatively constant $\delta^{56} \mathrm{Fe}$ regardless of geographical location or hydrology, and are similar to the composition of the continental crust. The $\delta^{56} \mathrm{Fe}$ of the dissolved load from land-terminating glaciers in Greenland is not uniform and varies geographically. The lowest $\delta^{56} \mathrm{Fe}$ values occur in the dissolved fraction of the stream draining the Russell Glacier (GKL), with $\delta^{56} \mathrm{Fe}$ as low as $-2.1 \%$. As this glacial outflows is inferred to be the only outflow (of those sampled) that is uniformally below ferrihydrite saturation, it suggests that GKL represents the most pristine Fe isotopic signal related to the release of $\mathrm{Fe}$ in the subglacial weathering environment. The major element chemistry of the dissolved loads supports the presence of a weathering gradient across the 
various GIS sites samples, from the GKL (least weathered) through GKL, GIL, GKU and, to GNR, the inferred most weathered. Mechanistically the data suggest a link between the extent of chemical weathering and $\delta^{56} \mathrm{Fe}$ of aqueous $\mathrm{Fe}$, with lighter $\delta^{56} \mathrm{Fe}$ representative of the least chemically weathered subglacial systems: at extremely low ionic strengths (early stages of incipient chemical weathering) dissolved loads take most negative $\delta^{56} \mathrm{Fe}$ compositions. At the highest ionic strength (inferred to be more extensively weathered system), we have the $\delta^{56} \mathrm{Fe}$ values that are similar to the crustal array and coexisting suspended sediments.

The fractionation associated with Fe-oxide precipitation is very important for determining the $\delta^{56} \mathrm{Fe}$ composition of the dissolved loads, yet is still a process that remains to be quantified in this study. PHREEQC calculations confirm the presence of Fe-oxide phases, but the extent of their control on the dissolved loads here, especially with regards to changing redox states and $\mathrm{pH}$, was not ascertained with the data presented here. Complex controls on the aqueous geochemistry of subglacial environments confound simple interpretations of $\mathrm{Fe}$ isotopic fractionation. We propose that the lighter isotopes of $\mathrm{Fe}$ are released during primary dissolution of silicate minerals, via $\mathrm{Fe}$ detachment during chemical weathering of bedload and suspended sediments. This hypothesis likely explains the lighter range of fractionation in the dissolved loads given the high rates of physical weathering and sediment generation. Whether this isotopic composition can be maintained downstream remains to be determined. Nevertheless, Fe speciation, redox control and mineral precipitation will also impact any subsequent isotopic signal generated after the initial stages of silicate weathering. The data illustrate that the dissolved Fe supplied by subglacial weathering can have variable $\delta^{56} \mathrm{Fe}$ values depending on the degree of chemical weathering. Thus, Fe isotopes may have potential as a proxy for subglacial chemical weathering intensity or mode.

\section{Acknowledgements}

We thank Air Greenland and Captain Sigurdur Petursson for logistical support. The Turner Postdoctoral Fellowship award to E.I.S. and the Packard Foundation Fellowship award to S.M.A funded this project. Iron isotope analytical work at Penn State was supported by NSF award EAR0959092 to M.S.F.. Field work at the SQS site was further supported by the Woods Hole Oceanographic Institution's Ocean and Climate Change Institute Arctic Research Initiative research grant to S.B.D.. We greatly thank Cody Sheik and Carli Arendt for field assistance and scientific discussions regarding the paper. We thank the three anonymous reviewers and Silke Severmann for their insight into the paper. We thank Huimin Yu for analytical support in running the $\mathrm{Fe}$ isotope samples at the Metal Isotope Laboratory (MIL) at Penn State, Donald V. Kenny for anion measurements at the Byrd Polar Research Center, Ohio State University, and finally Kevin Burton for the intellectual inception of this project. 


\section{References}

Aciego, S., Stevenson, E. I., and Arendt, C. A., 2015, Climate versus geological controls on glacial meltwater micronutrient production in southern Greenland: Earth and Planetary Science Letters, v. 424, p. 51-58.

Anbar, A. D., Jarzecki, A. A., and Spiro, T. G., 2005, Theoretical investigation of iron isotope fractionation between $\mathrm{Fe}(\mathrm{H} 2 \mathrm{O})(3+)(6)$ and $\mathrm{Fe}(\mathrm{H} 2 \mathrm{O})(2+)(6)$ : Implications for iron stable isotope geochemistry: Geochimica Et Cosmochimica Acta, v. 69, no. 4, p. 825-837.

Anbar, A. D., Roe, J. E., Barling, J., and Nealson, K. H., 2000, Nonbiological fractionation of iron isotopes: Science, v. 288, no. 5463, p. 126-128.

Anbar, A. D., and Rouxel, O., 2007, Metal stable isotopes in paleoceanography: Annual Review of Earth and Planetary Sciences, v. 35, p. 717-746.

Anderson, S.P., 2007, Biogeochemistry of glacial landscape systems: Annual Review of Earth and Planetary Sciences, v. 35, p. 375-399.

Anderson, S. P., 2005, Glaciers show direct linkage between erosion rate and chemical weathering fluxes: Geomorphology, v. 67, no. 1-2, p. 147-157.

Anderson, S. P., Drever, J. I., and Humphrey, N. F., 1997, Chemical weathering in glacial environments: Geology, v. 25, no. 5, p. 399-402.

Archer, C., and Vance, D., 2006, Coupled Fe and S isotope evidence for Archean microbial Fe(III) and sulfate reduction: Geology, v. 34, no. 3, p. 153-156.

Balci, N., Bullen, T. D., Witte-Lien, K., Shanks, W. C., Motelica, M., and Mandernack, K. W., 2006, Iron isotope fractionation during microbially stimulated $\mathrm{Fe}(\mathrm{II})$ oxidation and $\mathrm{Fe}(\mathrm{III})$ precipitation: Geochimica Et Cosmochimica Acta, v. 70, no. 3, p. 622-639.

Beard, B. L., and Johnson, C. M., 2004, Fe isotope variations in the modern and ancient earth and other planetary bodies: Geochemistry of Non-Traditional Stable Isotopes, v. 55, p. 319-357. 
Beard, B. L., Johnson, C. M., Skulan, J. L., Nealson, K. H., Cox, L., and Sun, H., 2003a, Application of Fe isotopes to tracing the geochemical and biological cycling of Fe: Chemical Geology, v. 195, no. $1-4$, p. $87-117$.

Beard, B. L., Johnson, C. M., Von Damm, K. L., and Poulson, R. L., 2003b, Iron isotope constraints on Fe cycling and mass balance in oxygenated Earth oceans: Geology, v. 31, no. 7, p. 629632.

Bergquist, B. A., and Boyle, E. A., 2006, Iron isotopes in the Amazon River system: Weathering and transport signatures: Earth and Planetary Science Letters, v. 248, no. 1-2, p. 54-68.

Berner, E. K., and Berner, R. A., 1996, Global Environment: Water, Air and Geochemical Cycles, Prentice Hall, Upper Saddle River, N. J.

Bhatia, M. P., Kujawinski, E. B., Das, S. B., Breier, C. F., Henderson, P. B., and Charette, M. A., 2013a, Greenland meltwater as a significant and potentially bioavailable source of iron to the ocean: Nature Geoscience, v. 6, no. 6, p. 503-503.

Bhatia, M. P., Das, S. B., Xu, L., Charette, M. A., Wadham, J.L., and Kujawinski, E. B.2013b, Organic carbon export from the Greenland ice Sheet. Geochimica Et Cosmochimica Acta v. 109, p. 329-344.

Boetius, A., Anesio, A.M., Deming, J.W., Mikucki, J.A., Rapp, J.Z., 2015, Microbial ecology of the cryosphere: sea ice and glacial habitats: Nature Reviews Microbiology, v. 13, p. 677-690.

Bottrell, S. H., and Tranter, M., 2002, Sulphide oxidation under partially anoxic conditions at the bed of the Haut Glacier d'Arolla, Switzerland: Hydrological Processes, v. 16, no. 12, p. 2363 2368.

Boyd, P. W., 2008, Implications of large-scale iron fertilization of the oceans - Introduction and synthesis: Marine Ecology Progress Series, v. 364, p. 213-218.

Boyd, P. W., and Ellwood, M. J., 2010, The biogeochemical cycle of iron in the ocean: Nature Geoscience, v. 3, no. 10, p. 675-682.

Boyd, P. W., Mackie, D. S., and Hunter, K. A., 2010, Aerosol iron deposition to the surface ocean Modes of iron supply and biological responses: Marine Chemistry, v. 120, no. 1-4, p. 128-143. 
Brantley, S. L., Liermann, L. J., Guynn, R. L., Anbar, A., Icopini, G. A., and Barling, J., 2004, Fe isotopic fractionation during mineral dissolution with and without bacteria: Geochimica Et Cosmochimica Acta, v. 68, no. 15, p. 3189-3204.

Bullen, T. D., White, A. F., Childs, C. W., Vivit, D. V., and Schulz, M. S., 2001, Demonstration of significant abiotic iron isotope fractionation in nature: Geology, v. 29, no. 8, p. 699-702.

Chapman, J. B., Weiss, D. J., Shan, Y., and Lemburger, M., 2009, Iron isotope fractionation during leaching of granite and basalt by hydrochloric and oxalic acids: Geochimica Et Cosmochimica Acta, v. 73, no. 5, p. 1312-1324.

Chen, J. B., Busigny, V., Gaillardet, J., Louvat, P., and Wang, Y. N., 2014, Iron isotopes in the Seine River (France): Natural versus anthropogenic sources: Geochimica Et Cosmochimica Acta, v. 128 , p. $128-143$.

Conway, T. M., and John, S. G., 2014, Quantification of dissolved iron sources to the North Atlantic Ocean: Nature, v. 511, no. 7508, p. 212-215.

Craddock, P. R., and Dauphas, N., 2010, Iron isotopic composition of reference materials, geostandards and chondrites: Geostandards and Geoanalytical Research, no. 35 p. 101-123.

Crusius, J., Schroth, A. W., Gasso, S., Moy, C. M., Levy, R. C., and Gatica, M., 2011, Glacial flour dust storms in the Gulf of Alaska: Hydrologic and meteorological controls and their importance as a source of bioavailable iron: Geophysical Research Letters, v. 38.

Dauphas, N., and Rouxel, O., 2006, Mass spectrometry and natural variations of iron isotopes: Mass Spectrometry Reviews, v. 25, no. 4, p. 515-550.

Dauphas, N., van Zuilen, M., Busigny, V., Lepland, A., Wadhwa, M., and Janney, P. E., 2007, Iron isotope, major and trace element characterization of early Archean supracrustal rocks from SW Greenland: Protolith identification and metamorphic overprint: Geochimica Et Cosmochimica Acta, v. 71, no. 19, p. 4745-4770.

Dauphas, N., van Zuilen, M., Wadhwa, M., Davis, A. M., Marty, B., and Janney, P. E., 2004, Clues from $\mathrm{Fe}$ isotope variations on the origin of early Archean BIFs from Greenland: Science, v. 306, no. 5704, p. 2077-2080. 
de Jong, J., Schoemann, V., Tison, J. L., Becquevort, S., Masson, F., Lannuzel, D., Petit, J., Chou, L., Weis, D., and Mattielli, N., 2007, Precise measurement of Fe isotopes in marine samples by multi-collector inductively coupled plasma mass spectrometry (MC-ICP-MS): Analytica Chimica Acta, v. 589, no. 1, p. 105-119.

Dideriksen, K., Baker, J. A., and Stipp, S. L. S., 2008, Equilibrium Fe isotope fractionation between inorganic aqueous Fe(III) and the siderophore complex, Fe(III)-desferrioxamine B: Earth and Planetary Science Letters, v. 269, no. 1-2, p. 280-290.

Escher, A., 1971, Map Sheet no. 3 Sondre Stromfjord - Nugssu aq Geological Maps of Greenland 1:500,000. Geological Survey of Denmark and Greenland (GEUS), Copenhagen.

Escoube, R., Rouxel, O., Pokrovski, O. S., Schroth, A. W., Holmes, R. M., and Donard, F. X., 2015, Iron isotope systematics in Arctic rivers: Comptes Rendus Geoscience, v. 347, p. 377-385.

Fan, S. M., Moxim, W. J., and Levy, H., 2006, Aeolian input of bioavailable iron to the ocean: Geophysical Research Letters, v. 33, no. 7.

Fantle, M. S., and DePaolo, D. J., 2004, Iron isotopic fractionation during continental weathering: Earth and Planetary Science Letters, v. 228, no. 3-4, p. 547-562.

French, H. M., 2007, The Periglacial Environment, 3rd edn., Chichester, Wiley.

Fujita, Y., Taylor, J. L., Gresham, T. L. T., Delwiche, M. E., Colwell, F. S., McLing, T. L., Petzke, L. M., and Smith, R. W., 2008, Stimulation of microbial urea hydrolysis in groundwater to enhance calcite precipitation: Environmental Science \& Technology, v. 42, no. 8, p. 30253032 .

Fung, I. Y., Meyn, S. K., Tegen, I., Doney, S. C., John, J. G., and Bishop, J. K. B., 2000, Iron supply and demand in the upper ocean: Global Biogeochemical Cycles, v. 14, no. 1, p. 281-295.

Guilbaud, R., Butler, I. B., and Ellam, R. M., 2011, Abiotic Pyrite Formation Produces a Large Fe Isotope Fractionation: Science, v. 332, no. 6037, p. 1548-1551.

Hawkings, J. R., Wadham, J. L., Tranter, M., Raiswell, R., Benning, L. G., Statham, P. J., Tedstone, A., Nienow, P., Lee, K., and Telling, J., 2014, Ice sheets as a significant source of highly reactive nanoparticulate iron to the oceans: Nature Communications, v. 5, p. 3929. 
Hedin, R. S., Watzlaf, G. R., and Nairn, R. W., 1994, Passive Treatment of Acid Mine Drainage with Limestone: Journal of Environmental Quality, v. 23, p. 1338-1345.

Henriksen, N., Higgins, A. K., Kalsbeek, F., and Pulvertaft, T. C. R., 2009, Greenland from Archaean to Quaternary Descriptive text to the 1995 Geological map of Greenland, 1:2 500 000. 2nd edition: Geological Survey of Denmark and Greenland Bulletin, no. 18, p. 9-116.

Hindshaw, R. S., Rickli, J., Leuthold, J., Wadham, J., Bourdon, B., 2014, Identifying weathering sources and processes in an outlet glacier of the Greenland Ice Sheet using $\mathrm{Ca}$ and $\mathrm{Sr}$ isotope ratios: Geochimica Et Cosmochimica Acta, v. 145, p. 50-71.

Hopwood, M.J., Bacon, S., Arendt, K., Connelly, D.P., Statham, P.J., 2015, Glacial meltwater from Greenland is not likely to be an important source of Fe to the North Atlantic: Biogeochemistry, v. 124, p. 1-11.

Howard, A. G., 2010, On the challenge of quantifying man-made nanoparticles in the aquatic environment: Journal of Environmental Monitoring, v. 12, no. 1, p. 135-142.

Ilina, S. M., Poitrasson, F., Lapitskiy, S. A., Alekhin, Y. V., Viers, J., and Pokrovsky, O. S., 2013, Extreme iron isotope fractionation between colloids and particles of boreal and temperate organic-rich waters: Geochimica Et Cosmochimica Acta, v. 101, p. 96-111.

Jickells, T. D., An, Z. S., Andersen, K. K., Baker, A. R., Bergametti, G., Brooks, N., Cao, J. J., Boyd, P. W., Duce, R. A., Hunter, K. A., Kawahata, H., Kubilay, N., laRoche, J., Liss, P. S., Mahowald, N., Prospero, J. M., Ridgwell, A. J., Tegen, I., and Torres, R., 2005, Global iron connections between desert dust, ocean biogeochemistry, and climate: Science, v. 308, no. 5718, p. 67-71.

Jickells, T. D., and Spokes, L. J., 2001, Atmospheric Iron Inputs to the Oceans: in Hunter, D. R. T. a. K. A., ed., The biogeochemistry of iron in seawater, Volume 7: Chichester New York, J. Wiley. , p. 85-121.

Johnson, C. M., and Beard, B. L., 2006, Fe Isotopes: An emerging technique for understanding modern and ancient biogeochemical cycles: GSA Today, v. 16, no. 11, p. 4-10. 
Johnson, C. M., Beard, B. L., and Roden, E. E., 2008, The iron isotope fingerprints of redox and biogeochemical cycling in the modern and ancient Earth: Annual Review of Earth and Planetary Sciences, v. 36, p. 457-493.

Johnson, C. M., Skulan, J. L., Beard, B. L., Sun, H., Nealson, K. H., and Braterman, P. S., 2002, Isotopic fractionation between $\mathrm{Fe}(\mathrm{III})$ and $\mathrm{Fe}(\mathrm{II})$ in aqueous solutions: Earth and Planetary Science Letters, v. 195, no. 1-2, p. 141-153.

Kiczka, M., Wiederhold, J. G., Frommer, J., Kraemer, S. M., Bourdon, B., and Kretzschmar, R., 2010, Iron isotope fractionation during proton- and ligand-promoted dissolution of primary phyllosilicates: Geochimica Et Cosmochimica Acta, v. 74, no. 11, p. 3112-3128.

Kiczka, M., Wiederhold, J. G., Frommer, J., Voegelin, A., Kraemer, S. M., Bourdon, B., and Kretzschmar, R., 2011, Iron speciation and isotope fractionation during silicate weathering and soil formation in an alpine glacier forefield chronosequence: Geochimica Et Cosmochimica Acta, v. 75, no. 19, p. 5559-5573.

Lewis, S. M., and Smith, L. C., 2009, Hydrologic drainage of the Greenland Ice Sheet: Hydrological Processes, v. 23, no. 14, p. 2004-2011.

Mahowald, N. M., Baker, A. R., Bergametti, G., Brooks, N., Duce, R. A., Jickells, T. D., Kubilay, N., Prospero, J. M., and Tegen, I., 2005, Atmospheric global dust cycle and iron inputs to the ocean: Global Biogeochemical Cycles, v. 19, no. 4.

Mahowald, N. M., Muhs, D. R., Levis, S., Rasch, P. J., Yoshioka, M., Zender, C. S., and Luo, C., 2006, Change in atmospheric mineral aerosols in response to climate: Last glacial period, preindustrial, modern, and doubled carbon dioxide climates: Journal of Geophysical ResearchAtmospheres, v. 111, D10202.

Martin, J. H., 1990, Glacial-Interglacial Co2 Change: The Iron Hypothesis: Paleoceanography, v. 5, no. 1, p. 1-13.

Martin, J. H., Broenkow, W. W., Fitzwater, S. E., and Gordon, R. M., 1990, Does Iron Really Limit Phytoplankton Production in the Offshore Subarctic Pacific - Yes, It Does - A Reply: Limnology and Oceanography v. 35, no. 3, p. 775-777. 
Martin, J. H., Coale, K. H., Johnson, K. S., Fitzwater, S. E., Gordon, R. M., Tanner, S. J., Hunter, C. N., Elrod, V. A., Nowicki, J. L., Coley, T. L., Barber, R. T., Lindley, S., Watson, A. J., Vanscoy, K., Law, C. S., Liddicoat, M. I., Ling, R., Stanton, T., Stockel, J., Collins, C., Anderson, A., Bidigare, R., Ondrusek, M., Latasa, M., Millero, F. J., Lee, K., Yao, W., Zhang, J. Z., Friederich, G., Sakamoto, C., Chavez, F., Buck, K., Kolber, Z., Greene, R., Falkowski, P., Chisholm, S. W., Hoge, F., Swift, R., Yungel, J., Turner, S., Nightingale, P., Hatton, A., Liss, P., and Tindale, N. W., 1994, Testing the Iron Hypothesis in Ecosystems of the Equatorial Pacific-Ocean: Nature, v. 371, no. 6493, p. 123-129.

Martin, J. H., and Fitzwater, S. E., 1988, Iron-Deficiency Limits Phytoplankton Growth in the Northeast Pacific Subarctic: Nature, v. 331, no. 6154, p. 341-343.

Martin, J. H., Fitzwater, S. E., and Gordon, R. M., 1991, We Still Say Iron-Deficiency Limits Phytoplankton Growth in the Sub-Arctic Pacific: Journal of Geophysical Research-Oceans, v. 96, no. C11, p. 20699-20700.

Mikutta, C., Wiederhold, J. G., Cirpka, O. A., Hofstetter, T. B., Bourdon, B., and Von Gunten, U., 2009, Iron isotope fractionation and atom exchange during sorption of ferrous iron to mineral surfaces: Geochimica Et Cosmochimica Acta, v. 73, no. 7, p. 1795-1812.

Mikucki, J. A., Pearson, A., Johnston, D.T., Turchyn, A.V., Farquhar, J., Schrag, D.P., Anbar, A.D., Priscu, J.C., Lee, P.A., 2009, A Contemporary Microbailly Maintained Subglacial Ferrous "Ocean". Science, v. 342, p. 397-400.

Mitchell, A. C., and Brown, G. H., 2008, Modeling geochemical and biogeochemical reactions in subglacial environments: Arctic Antarctic and Alpine Research, v. 40, no. 3, p. 531-547.

Parkhurst, D. L., and Appelo, C. A. J., 1999, User's guide to PHREEQC (version 2)--A computer program for speciation, batch-reaction, one-dimensional transport, and inverse geochemical calculations: U.S. Geological Survey Water-Resources Investigations Report 99-4259, v. 994259, p. 312.

Percak-Dennett, E.M., Beard, B.L., Xu, H., Konishi, H., Johnson, C.M., Roden, E.E., 2011, iron isotope fractionation during microbial dissimilatory iron oxide reduced in simulated Archean seawater: Geobiology, v. 9, p. 205-220. 
Poitrasson, F., 2006, On the iron isotope homogeneity level of the continental crust: Chemical Geology, v. 235, no. 1-2, p. 195-200.

Poitrasson, F., and Freydier, R., 2005, Heavy iron isotope composition of granites determined by high resolution MC-ICP-MS: Chemical Geology, v. 222, no. 1-2, p. 132-147.

Raiswell, R., and Canfield, D. E., 2012, The Iron Biogeochemical Cycle Past and Present: Geochemical Perspectives, v. 1, no. 1, p. 1-220.

Rignot, E., Velicogna, L., van den Broeke, M., Monaghan, A., Lenaerts, J., 2011, Acceleration of the contribution of the Greenland and Antarctic ice sheets to sea level rise: Geophysical Research Letters, v. 38., L05503

Rouxel, O.J., Bekker, A., and Edwards, K., 2005, Iron isotope constraints on the Archean and Paleoproterozoic ocean redox state: Geochimica Et Cosmochimica Acta, v. 69, no. 10, p. A549-A549.

Rouxel, O.J., Auro, M., 2010, Iron Isotope Variations in Coastal Seawater Determined by Multicollector ICP-MS: Geostandards and Geoanalytical Research, v. 34(2), p.135-144.

Ryu, J. S., Jacobson, A. D., Holmden, C., Lundstrom, C., and Zhang, Z. F., 2011, The major ion, delta $\mathrm{Ca}-44 / 40$, delta Ca-44/42, and delta Mg-26/24 geochemistry of granite weathering at $\mathrm{pH}=1$ and $\mathrm{T}=25$ degrees $\mathrm{C}$ : power-law processes and the relative reactivity of minerals: Geochimica Et Cosmochimica Acta, v. 75, no. 20, p. 6004-6026.

Sasgen, I., van den Broeke, M., Bamber, J. L., Rignot, E., Sorensen, L. S., Wouters, B., Martinec, Z., Velicogna, I., and Simonsen, S. B., 2012, Timing and origin of recent regional ice-mass loss in Greenland: Earth and Planetary Science Letters, v. 333, p. 293-303.

Schroth, A. W., Crusius, J., Chever, F., Bostick, B. C., and Rouxel, O. J., 2011, Glacial influence on the geochemistry of riverine iron fluxes to the Gulf of Alaska and effects of deglaciation: Geophysical Research Letters, v. 38., n. 16.

Schroth, A. W., Crusius, J., Hoyer, I., and Campbell, R., 2014, Estuarine removal of glacial iron and implications for iron fluxes to the ocean: Geophysical Research Letters, v. 41, no. 11, p. 39513958. 
Schuth, S., Hurrass, J., Munker, C., and Mansfeldt, T., 2015, Redox-dependent fractionation of iron isotopes in suspensions of a groundwater-influenced soil: Chemical Geology, v. 392, p. 74-86.

Sharp, M., Parkes, J., Cragg, B., Fairchild, I. J., Lamb, H., and Tranter, M., 1999, Widespread bacterial populations at glacier beds and their relationship to rock weathering and carbon cycling: Geology, v. 27, no. 2, p. 107-110.

Skulan, J. L., Beard, B. L., and Johnson, C. M., 2002, Kinetic and equilibrium Fe isotope fractionation between aqueous Fe(III) and hematite: Geochimica Et Cosmochimica Acta, v. 66, no. 17, p. 2995-3015.

Statham, P. J., Skidmore, M., and Tranter, M., 2008, Inputs of glacially derived dissolved and colloidal iron to the coastal ocean and implications for primary productivity: Global Biogeochemical Cycles, v. 22, GB3013.

Stevens, L. A., Straneo, F., Das, S. B., Plueddemann, A. J., Kukulya, A. L., and Morlighem, M., 2016, Linking glacially modified waters to catchment-scale subglacial discharge using autonomous underwater vehicle observations: Cryosphere, v. 10, no. 1, p. 417-432.

Thompson, A., Ruiz, J., Chadwick, O. A., Titus, M., and Chorover, J., 2007, Rayleigh fractionation of iron isotopes during pedogenesis along a climate sequence of Hawaiian basalt: Chemical Geology, v. 238, no. 1-2, p. 72-83.

Tranter, M., Lamb, H., Bottrell, S., Raiswell, R., Sharp, M., and Brown, G., 1997, Tracing bedrock weathering and hydrologic flowpaths beneath an Alpine glacier using delta S-34 and Sr-87/Sr86: Hydrochemistry, no. 244, p. 317-324.

Tranter, M., Sharp, M. J., Lamb, H. R., Brown, G. H., Hubbard, B. P., and Willis, I. C., 2002, Geochemical weathering at the bed of Haut Glacier d'Arolla, Switzerland - a new model: Hydrological Processes, v. 16, no. 5, p. 959-993.

Tranter, M., and Wadham, J., 2014, Geochemical Weathering in Glacial and Proglacial Environments, in Turekian, H. H. a. K., ed., Treatise on Geochemistry (Second Edition), Volume 7, Elsevier Ltd, p. 157-173. 
Wadham, J. L., Bottrell, S., Tranter, M., and Raiswell, R., 2004, Stable isotope evidence for microbial sulphate reduction at the bed of a polythermal high Arctic glacier: Earth and Planetary Science Letters, v. 219, no. 3-4, p. 341-355.

Wadham, J. L., De'ath, R., Monteiro, F. M., Tranter, M., Ridgwell, A., Raiswell, R., and Tulaczyk, S., 2013, The potential role of the Antarctic Ice Sheet in global biogeochemical cycles: Earth and Environmental Science Transactions of the Royal Society of Edinburgh, v. 104, no. 1, p. 5567.

Wadham, J. L., Tranter, M., Hodson, A. J., Hodgkins, R., Bottrell, S., Cooper, R., and Raiswell, R., 2010a, Hydro-biogeochemical coupling beneath a large polythermal Arctic glacier: Implications for subice sheet biogeochemistry: Journal of Geophysical Research-Earth Surface, v. 115., F04017.

Wadham, J. L., Tranter, M., Skidmore, M., Hodson, A. J., Priscu, J., Lyons, W. B., Sharp, M., Wynn, P., and Jackson, M., 2010b, c: Global Biogeochemical Cycles, v. 24., GB003688

Welch, S. A., Beard, B. L., Johnson, C. M., and Braterman, P. S., 2003, Kinetic and equilibrium Fe isotope fractionation between aqueous $\mathrm{Fe}(\mathrm{II})$ and $\mathrm{Fe}(\mathrm{III})$ : Geochimica Et Cosmochimica Acta, v. 67 , no. 22 , p. $4231-4250$.

Whitehouse, M. J., and Fedo, C. M., 2007, Microscale heterogeneity of Fe isotopes in > $3.71 \mathrm{Ga}$ banded iron formation from the Isua Greenstone Belt, Southwest Greenland: Geology, v. 35, no. 8 , p. 719-722.

Wiederhold, J. G., Kraemer, S. M., Teutsch, N., Borer, P. M., Halliday, A. N., and Kretzschmar, R., 2006, Iron isotope fractionation during proton-promoted, ligand-controlled, and reductive dissolution of goethite: Environmental Science \& Technology, v. 40, no. 12, p. 3787-3793.

Wiederhold, J. G., Teutsch, N., Kraemer, S. M., Halliday, A. N., and Kretzschmar, R., 2007a, Iron isotope fractionation during pedogenesis in redoximorphic soils: Soil Science Society of America Journal, v. 71, no. 6, p. 1840-1850.

Wiederhold, J. G., Teutsch, N.,Kraemer, S. M.,Halliday, A. N.,Kretzschmar, R., 2007b, Iron isotope fractionation in oxic soils by mineral weathering and podzolization: Geochimica Et Cosmochimica Acta, v. 71, no. 23, p. 5821-5833. 
Williams, H. M., McCammon, C. A., Peslier, A. H., Halliday, A. N., Teutsch, N., Levasseur, S., and Burg, J. P., 2004, Iron isotope fractionation and the oxygen fugacity of the mantle: Science, v. 304 , no. 5677 , p. $1656-1659$.

Wynn, P. M., Hodson, A., and Heaton, T., 2006, Chemical and isotopic switching within the subglacial environment of a High Arctic glacier: Biogeochemistry, v. 78, no. 2, p. 173-193.

Yesavage, T., Fantle, M. S., Vervoort, J., Mathur, R., Jin, L. X., Liermann, L. J., and Brantley, S. L., 2012, Fe cycling in the Shale Hills Critical Zone Observatory, Pennsylvania: An analysis of biogeochemical weathering and $\mathrm{Fe}$ isotope fractionation: Geochimica Et Cosmochimica Acta, v. 99, p. 18-38.

Zambardi, T., Lundstrom, C. C., Li, X. X., and McCurry, M., 2014, Fe and Si isotope variations at Cedar Butte volcano; insight into magmatic differentiation: Earth and Planetary Science Letters, v. 405, p. 169-179.

Zhang, R. F., John, S. G., Zhang, J., Ren, J. L., Wu, Y., Zhu, Z. Y., Liu, S. M., Zhu, X. C., Marsay, C. M., and Wenger, F., 2015, Transport and reaction of iron and iron stable isotopes in glacial meltwaters on Svalbard near Kongsfjorden: From rivers to estuary to ocean: Earth and Planetary Science Letters, v. 424, p. 201-211.

Supplemental Figure 1: 


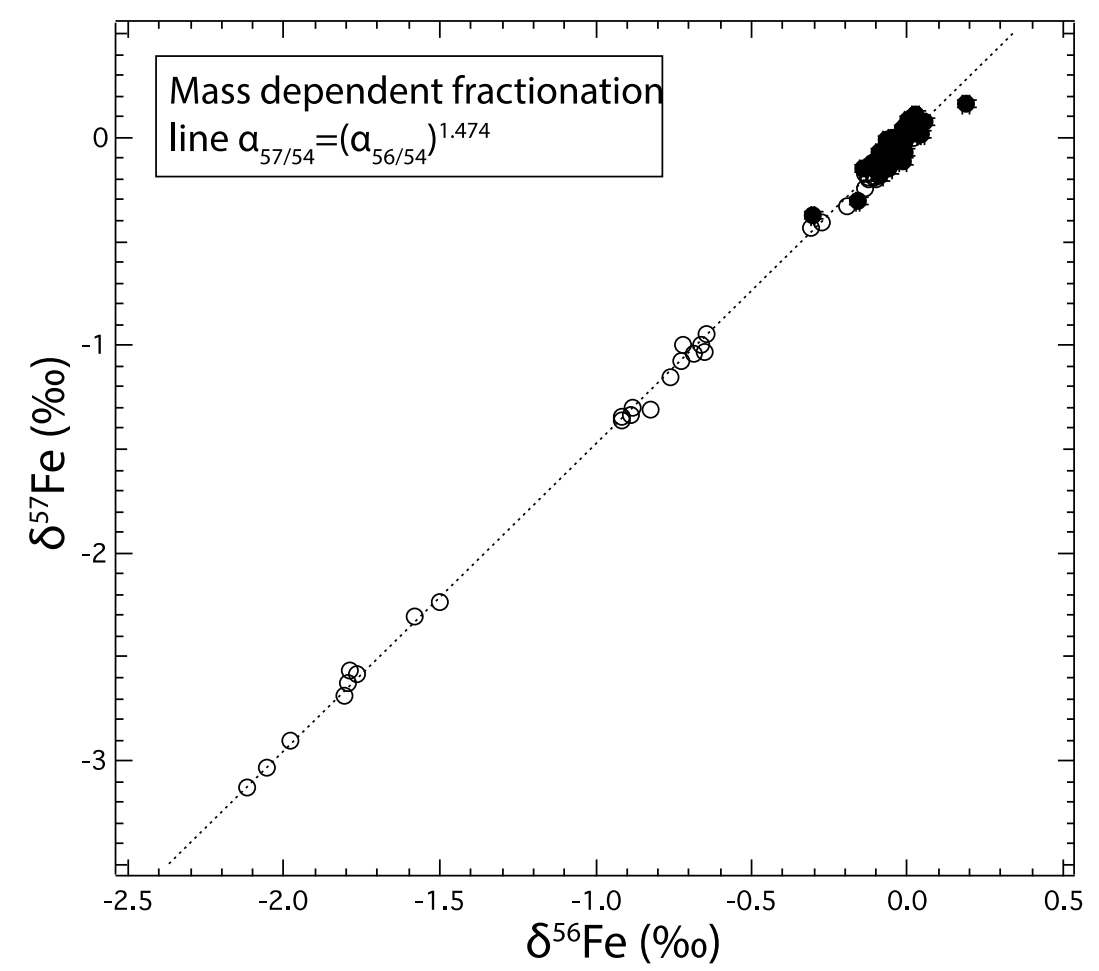

Terrestrial mass fractionation line $\left(\delta^{56} \mathrm{Fe}\right.$ versus $\left.\delta^{57} \mathrm{Fe}\right)$. All sample lie within error of the mass fraction line defined as $\alpha_{57 / 54}=\left(\alpha_{56 / 54}\right)^{1.474}$ (Beard and Johnson, 2004). Only sample and sample replicates shown, white symbols are dissolved loads and black symbols are suspended sediments.

Supplemental information 1: Tab 1: In situ measurements, cation and anion concentration data measured in this study. Procedural blanks, standard data and detections limits included in the table. Data in italics are from Aciego et al. (2015). Tab 2: Raw output PHREEQC data (units are saturation index Tab 2: Output of mineral saturation states (SI units) from PHREEQC modeling for the GIL. 


\begin{tabular}{|c|c|c|c|c|c|c|c|c|c|c|c|c|}
\hline Sample & $\begin{array}{c}\text { Specific } \\
\text { Conductivity } \\
\mu \mathrm{S} \mathrm{m}^{-1} *\end{array}$ & $\underset{ }{\text { Temp }}{ }^{\circ} C^{*}$ & $\mathrm{Na} \mu \mathrm{mol}$ & $\mathrm{Mg} \mu \mathrm{mol}$ & $\mathrm{Al} \mu \mathrm{mol}$ & Si $\mu \mathrm{mol}$ & $\mathrm{K} \mu \mathrm{mol}$ & $\mathrm{Ca} \mu \mathrm{mol}$ & $\mathrm{Fe} \mu \mathrm{mol}$ & $\begin{array}{l}\mathrm{SO}_{4}^{2-} \\
\mu \mathrm{mol}\end{array}$ & $\mathrm{Cl}^{-} \mu \mathrm{mol}$ & $\begin{array}{c}\text { Alkalinity } \\
\mu \mathrm{mol} \mathrm{HCO}_{3}^{-}\end{array}$ \\
\hline Detection limits & $\pm 0.5 \%$ & $\pm 0.2^{\circ} \mathrm{C}$ & 0.60 & 0.20 & 0.05 & 0.50 & 0.05 & 0.50 & 0.02 & 0.02 & 0.01 & \\
\hline $\begin{array}{c}\text { Procedural } \\
\text { Blank }\end{array}$ & & & 0.60 & 0.30 & 0.10 & 0.80 & 0.10 & 0.60 & 0.05 & n.d. & n.d. & \\
\hline $\begin{array}{l}\text { NIST1640a } \\
\quad(n=4)\end{array}$ & & & $132 \pm 2$ & $45 \pm 1$ & $3.0 \pm 0.4$ & $153 \pm 3$ & $15.4 \pm 0.3$ & $152 \pm 3$ & $0.69 \pm 0.01$ & & & \\
\hline $\begin{array}{l}\text { NIST1640a } \\
\text { certified }\end{array}$ & & & 135.36 & 43.21 & 1.96 & 184.05 & 14.71 & 138.98 & 0.66 & & & \\
\hline$A G V-2(n=5)$ & & & 1256654.49 & 355186.09 & 3009598.35 & - & 575912.81 & 775472.92 & 767993.89 & & & \\
\hline $\begin{array}{c}\text { AGV-2 } \\
\text { literature }\end{array}$ & & & 1352775.60 & 444353.01 & 3317087.63 & - & 611279.77 & 928190.03 & 838033.84 & & & \\
\hline BCR-2 (n=2) & & & 1027361.33 & 844936.44 & 2615455.71 & - & 383301.17 & 1260375.44 & 1667718.19 & & & \\
\hline BCR-2 literature & & & 1000444.98 & 888706.03 & 2646257.62 & - & 381090.74 & 1270023.45 & 1729787.81 & & & \\
\hline GNR-200713 & 12.40 & 0.90 & 22.14 & 20.78 & 13.56 & 35.96 & 17.24 & 94.57 & 6.97 & 12.59 & 6.61 & 6.54 \\
\hline GNR-210713 & 12.40 & 1.00 & 26.19 & 13.45 & 3.74 & 19.83 & 19.39 & 90.82 & 0.98 & 12.82 & 6.81 & 7.02 \\
\hline GNR-220713 & 11.90 & 0.90 & 22.53 & 16.54 & 7.08 & 25.74 & 16.85 & 93.32 & 4.17 & 12.51 & 6.28 & 7.20 \\
\hline GNR-240713 & 11.70 & 0.60 & 118.31 & 26.95 & 7.49 & 24.89 & 15.63 & 83.09 & 4.12 & 10.94 & 5.52 & 4.56 \\
\hline GIL-290713 & 1.90 & 0 & 135.71 & 29.79 & 13.01 & 25.85 & 16.24 & 33.43 & 7.22 & 157.08 & 1777.97 & 32.89 \\
\hline GLK-0308313a & 1.6 & 0.00 & 4.13 & 3.62 & 0.50 & 5.55 & 4.45 & 10.43 & 0.71 & 5.49 & 3.42 & 1.74 \\
\hline GLK-030813b & 1.4 & 0.10 & 3.04 & 2.51 & 0.26 & 4.66 & 2.66 & 8.98 & 0.42 & 5.35 & 1.66 & 1.86 \\
\hline GLK-040813b & 2.4 & 0.10 & 3.22 & 4.36 & 0.16 & 7.05 & 3.15 & 14.00 & 0.45 & 6.04 & 1.59 & 2.04 \\
\hline GLK-040813a & 1.5 & 0.00 & 3.18 & 2.84 & 0.22 & 4.70 & 4.04 & 8.71 & 0.44 & 3.88 & 0.42 & 1.56 \\
\hline GNU-060813 & 5.6 & 0.00 & 23.64 & 6.53 & 1.65 & 18.00 & 21.21 & 32.23 & 0.13 & 16.17 & 1.69 & 14.82 \\
\hline GNU-070813 & 8.3 & 0.00 & 28.84 & 7.94 & 1.72 & 19.30 & 20.95 & 40.17 & 0.25 & 26.43 & 4.86 & 6.36 \\
\hline GNU-080813 & 7.5 & 0.00 & 24.36 & 6.62 & 1.72 & 17.59 & 19.23 & 34.93 & 0.31 & 22.75 & 2.27 & 5.88 \\
\hline GKU-110813 & 8.2 & 1 & 56.98 & 12.01 & 0.54 & 8.87 & 13.50 & 36.93 & 0.26 & 42.36 & 52.41 & 3.72 \\
\hline GKU-120813 & 13.2 & 0.3 & 35.45 & 9.18 & 0.19 & 8.08 & 11.18 & 29.94 & 0.28 & 35.20 & 16.13 & 3.72 \\
\hline GKU-130813 & 5.3 & 0.4 & 26.32 & 7.49 & 0.40 & 5.73 & 8.11 & 25.20 & 0.30 & 26.25 & 9.84 & 2.88 \\
\hline GKU-140813a & 5.4 & 0.3 & 74.82 & 14.03 & 0.36 & 5.66 & 9.49 & 28.44 & 0.28 & 23.65 & 3.17 & 3.84 \\
\hline GKU-140813b & 3.7 & 0.3 & 33.28 & 7.65 & 0.33 & 5.48 & 7.60 & 24.20 & 0.31 & 18.77 & 2.61 & 1.68 \\
\hline
\end{tabular}




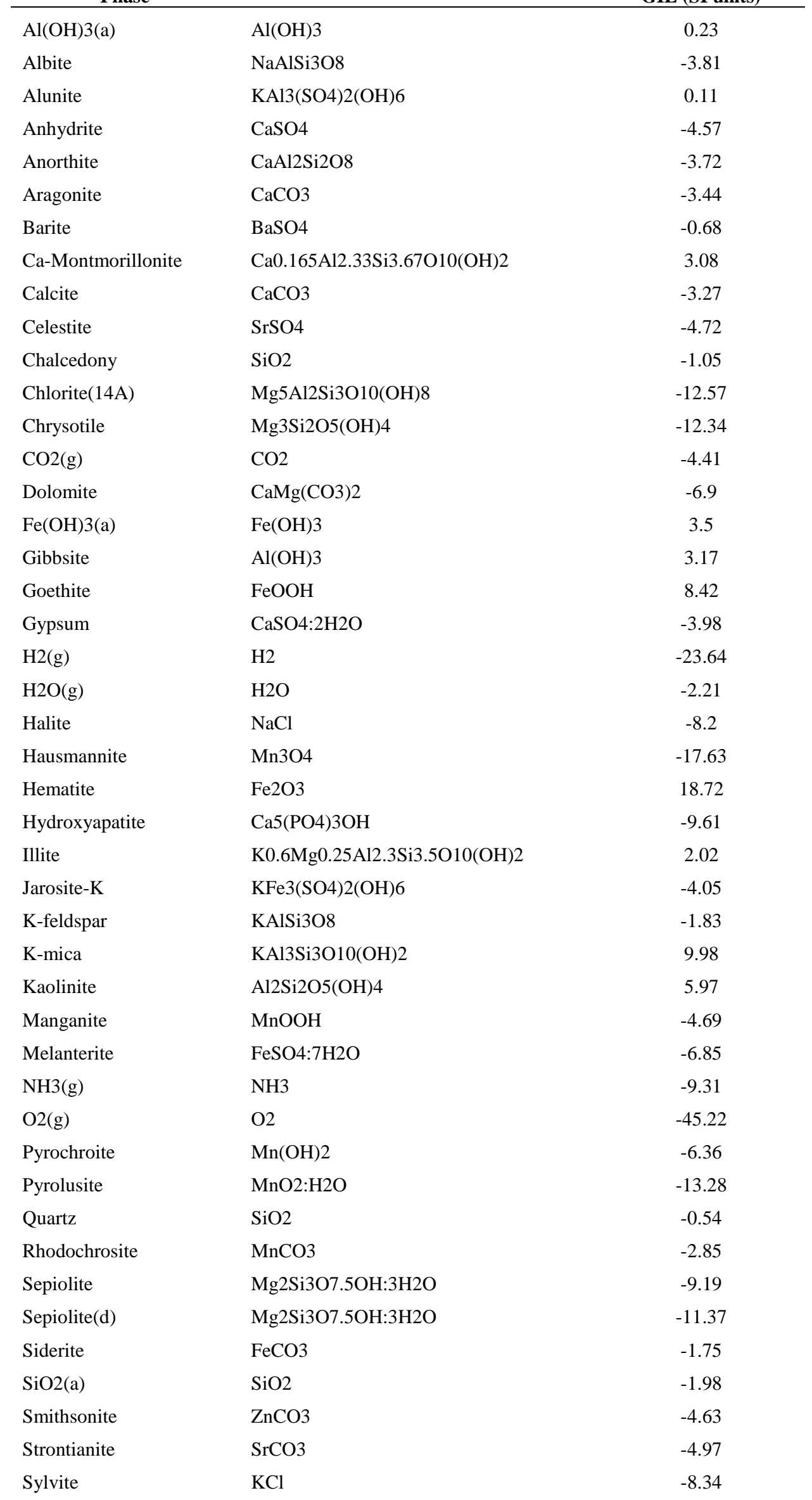


Talc

Vivianite

Willemite

Witherite

$\mathrm{Zn}(\mathrm{OH}) 2(\mathrm{e})$
$\mathrm{Mg} 3 \mathrm{Si} 4 \mathrm{O} 10(\mathrm{OH}) 2$

$-11.12$

$\mathrm{Fe} 3(\mathrm{PO} 4) 2: 8 \mathrm{H} 2 \mathrm{O}$

$-2.39$

$\mathrm{Zn} 2 \mathrm{SiO} 4$

$-5.7$

$\mathrm{BaCO} 3$

$\mathrm{Zn}(\mathrm{OH}) 2$
$-5.47$

$-3.11$

1076 